Article

\title{
Phytosterol, Lipid and Phenolic Composition, and Biological Activities of Guava Seed Oil
}

\author{
Adchara Prommaban ${ }^{1}$, Niramon Utama-ang ${ }^{2}$, Anan Chaikitwattana ${ }^{3}$, Chairat Uthaipibull ${ }^{4} \mathbb{D}^{\circ}$, \\ John B. Porter ${ }^{5}$ and Somdet Srichairatanakool ${ }^{1, *(D)}$ \\ 1 Department of Biochemistry, Faculty of Medicine, Chiang Mai University, Chiang Mai 50200, Thailand; \\ waewaa@gmail.com \\ 2 Department of Product Development Technology, Faculty of Agro-Industry, Chiang Mai University, \\ Chiang Mai 50200, Thailand; niramon.u@cmu.ac.th \\ 3 Department of Herb and Extract Business Development, Tipco Biotech Company, Prachuapkhirikhan 77000, \\ Thailand; anan@tipco.net \\ 4 Protein-Ligand Engineering and Molecular Biology Laboratory, National Center for Genetic Engineering and \\ Biotechnology (BIOTEC), National Science and Technology Development Agency, Thailand Science Park, \\ Pathum Thani 12120, Thailand; chairat@biotec.or.th \\ 5 Department of Haematology, O'Gormond Building, Institute of Cancer Research, Huntley Street, \\ University College London, London WC1E 6BT, UK; j.porter@ucl.ac.uk \\ * Correspondence: somdet.s@cmu.ac.th; Tel.: +66-5393-5322; Fax: +66-5389-4031
}

Academic Editor: Panagiotis Zoumpoulakis

Received: 30 April 2020; Accepted: 20 May 2020; Published: 27 May 2020

\begin{abstract}
Plant seeds have been found to contain bioactive compounds that have potential nutraceutical benefits. Guava seeds (Psidium guajava) are by-products in the beverage and juice industry; however, they can be utilized for a variety of commercial purposes. This study was designed to analyze the phytochemicals of the $n$-hexane extract of guava seed oil (GSO), to study its free-radical scavenging activity, and to monitor the changes in serum lipids and fatty acid profiles in rats that were fed GSO. The GSO was analyzed for phytochemicals using chromatographic methods. It was also tested for free-radical scavenging activity in hepatoma and neuroblastoma cells, and analyzed in terms of serum lipids and fatty acids. GSO was found to contain phenolic compounds (e.g., chlorogenic acid and its derivatives) and phytosterols (e.g., stimasterol, $\beta$-sitosterol and campesterol), and exerted radical-scavenging activity in cell cultures in a concentration-dependent manner. Long-term consumption of GSO did not increase cholesterol and triglyceride levels in rat serum, but it tended to decrease serum fatty acid levels in a concentration-dependent manner. This is the first study to report on the lipid, phytosterol and phenolic compositions, antioxidant activity, and the hepato- and neuro-protection of hydrogen peroxide-induced oxidative stress levels in the GSO extract.
\end{abstract}

Keywords: Psidium guajava; seed; hexane extract; lipid; phenolic compounds; phytosterols; antioxidant

\section{Introduction}

Guava (Psidium guajava L. Family Myrtaceae) is an important edible tropical fruit and a well-known herbal plant that has been widely applied in folk and traditional medicine [1,2]. The leaves are known to exhibit free-radical scavenging, inotropic, anti-glycemic, anti-hyperlipidemic, anti-hypertensive, and anti-diarrheal activities [3-8]. The pulp and peel have been known to exert anti-neoplastic effects on the induction of apoptosis and cell differentiation [9]. Guava seeds, a by-product of the beverage and juice processing industry, are abundant in dietary fiber, proteins, fats, phenolics, flavonol glycosides, 
glutelins, tannins, saponin and amino acids [10-14]. In addition, guava seed oil (GSO) obtained from red (P. cattleianum Sabin) and yellow (P. cattleianum var. lucidum Hort.) strawberry guava plants was found to contain high amounts of fatty acids, of which linoleic acid (LA) was the most abundant [15].

Different methods/agents, involving heat, boiling, roasting, detergents and organic solvents, have been used to obtain functional guava seed extracts. Additionally, GSO can be extracted by using organic solvents such as acetone, petroleum ether, ethyl acetate and $n$-hexane. For example, the sodium dodecyl sulfate extract of the seeds was shown to produce high yields of proteins that were mostly glutelins [12]. Acetone extracts of the seeds were found to contain flavonoids, phenolics and phenylethanoid glycosides [16]. The petroleum ether extract of GSO contained high amounts of linoleic acid, while the $n$-hexane extract of GSO predominantly contained linoleic acid $[17,18]$. Likewise, $\alpha$-tocopherol and $\delta$-tocopherol were found to be present in GSO. Notably, the quantity and nature of the tocopherols is of crucial importance regarding their oxidative stability [17]. Among organic solvents, $n$-hexane was found to be the most efficient in fractionating a wide range of lipophilic bioactive phytochemicals [19-21].

GSO possessed strong anti-oxidation and inhibitory activities against low-density lipoprotein peroxidation and Gram-negative bacteria [22,23]. Recently, we have revealed that the edible hexane extract of GSO is rich in linoleic acid, and contains some amounts of tocopherols, tocotrienols and phenolic compounds [24]. It is highly likely that phytochemicals in GSO present nutraceutical effects and benefits for health in humans. The aims of this study were to identify phenolic compounds, phytosterols and lipids in the GSO using very sensitive chromatographic/mass spectrometric methods, investigate the free-radical scavenging activity in hepatocytes and neuroblastoma cells, and evaluate the serum lipid levels in rats that had been fed GSO.

\section{Results}

\subsection{Identification of Lipids}

Here, we present the high-performance liquid chromatography-electrospray ionization-quadrupole-time of flight/mass spectrometry (HPLC-ESI-Q-TOF/MS) techniques, that possess high efficiency, specificity and sensitivity for the detection and characterization of tentative lipids in GSO. Though 13 peaks were resolved by chromatographic separation, only 6 peaks (No. 1-6) were identified using the Analysis Software, and these represented the tentative compounds identified as 4-hexyl-decanoic acid, sphinganine, 5S-hydroxyeicosatetraenoyl di-endoperoxide, didrovaltratum, sphingofungin B, 13,14-dihydro-19(R)-hydroxyprostaglandin E1, eschscholtzxanthin, tetradecan-3-one and xestoaminol $C$ (Figure 1 and Figure S1, Table 1). 
Table 1. Qualitative analysis for lipids in guava seed oil using HPLC-ESI-QTOF/MS.

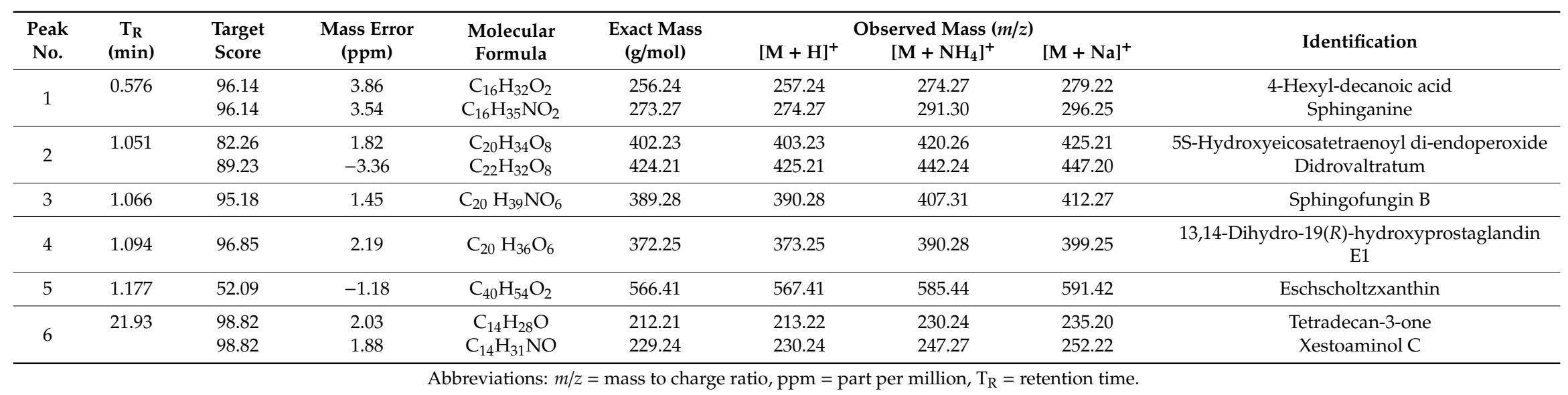




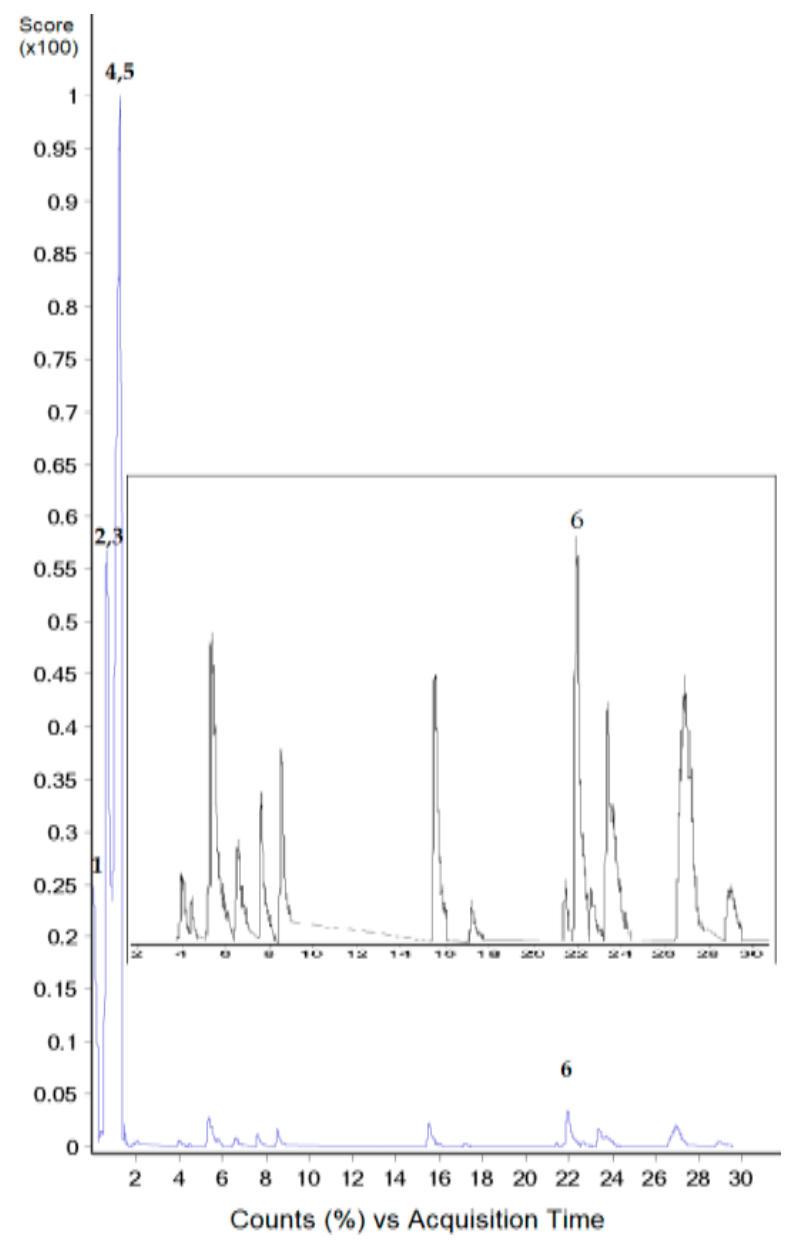

Figure 1. HPLC-ESI-QTOF/MS profile of lipids in guava seed oil. Inserted figure shows a magnification of area between 2 and $30 \mathrm{~min}$.

\subsection{Identification of Phytosterols}

For the detection of polar constituents, trimethysilyl (TMS) obtained from $N$-methyl- $N$-trimethylsilyltrifluoroacetamide (MSTFA) was able to derivatize certain multiple-functional groups, including hydroxyl, amine, sulfate, and carboxyl groups. Hence, the TMS derivatization of phytosterols and free fatty acids present in hexane extracts of GSO will enhance the performance of gas chromatographic/mass spectrometric (GC/MS) analysis, and provide characteristic ions in their electrospray ionization (ESI)-mass spectra. For the identification of targeted compounds, the ESI-mass fragmentations of several types of analytes were preferentially studied based on the mass spectra of the authentic standards (such as stimasterol, $\beta$-sitosterol, sitostanal and campesterol) and the internal standard cholestane. Most of the TMS derivatives and fatty acyl esters produced weak or intense molecular ions, abundant $[\mathrm{M}-73]^{+}$ions, and certain characteristic ions in their ESI-mass spectra, thereby providing easy identification. The mass fragmentation pathways of TMS-derivatized phytosterols and fatty acids were suggested and could be tentatively identified. Total ion chromatograms (TIC), and the corresponding ESI-mass spectra of typical TMS-derivatized fatty acids and phytosterols, for GSO are shown in Figure 2 and Figure S2. 


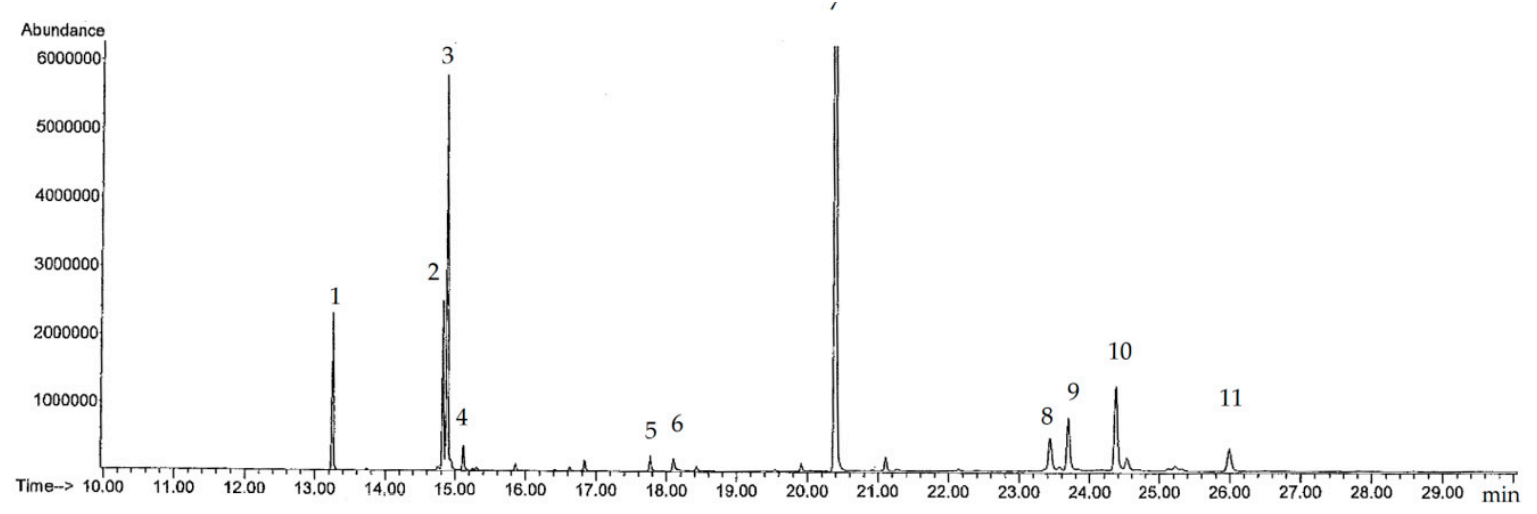

Figure 2. Total ion counts of phytosterols and lipids in guava seed oil analyzed using trimethylsillyl (TMS) derivatization-gas chromatography/mass spectrometry (GC/MS).

Using the gas chromatography/mass spectrometry (GC/MS) scan mode, peak numbers 1-10 were identified by comparing the retention times $\left(\mathrm{T}_{\mathrm{R}}\right)$ of 13.25, 14.83, 14.89, 15.12, 17.70, 18.10, 20.41, 23.44, 23.70 and $24.37 \mathrm{~min}$, respectively, and by comparing ESI-mass spectra against those of their authentic standards. Minor components with less than $0.1 \%$ relative abundance in the TIC were not considered of interest. As a result, they were identified as ethyl palmitate, ethyll linolenate, ethyl linoleate, ethyl stearate, linoleic acid, linolenic acid, cholestane, $\beta$-sitosterol, stigmasterol and campesterol, while sitostanal was not detected (Table 2). In stoichiometry, the amounts of $\beta$-stimasterol, $\beta$-sitosterol and campesterol were found to be 297.61, 0.22 and $11.04 \mathrm{mg} / 100 \mathrm{~g}$ GSO, respectively. This GC/MS method, combined with TMS derivatization, is a comprehensive chemical method for the profiling analysis and quantitation of phytosterols in GSO. Taken together, all the chromatographic analyses can provide relevant information on GSO by way of a direct comparison of its chemical composition with the biological activities in the present study. Furthermore, such information will be useful for predicting the biological and pharmacologic effects of GSO in subsequent studies.

Table 2. Identification of phytosterols and lipids in guava seed oil using TMS derivatization-GC/MS.

\begin{tabular}{|c|c|c|c|c|c|c|c|}
\hline $\begin{array}{l}\text { Peak } \\
\text { No. }\end{array}$ & $\begin{array}{c}\mathrm{T}_{\mathrm{R}} \\
(\mathrm{min})\end{array}$ & TIC & $\begin{array}{c}\text { Exact } \\
\text { Mass } \\
\text { (g/mol) }\end{array}$ & $\begin{array}{l}\text { Molecular } \\
\text { Formula }\end{array}$ & $\begin{array}{c}\text { Observed } \\
\text { Mass } \\
(\mathrm{m} / \mathrm{z})\end{array}$ & $\begin{array}{c}\text { Error } \\
(\%)\end{array}$ & Identification \\
\hline 1 & 13.25 & 2277755 & 284.5 & $\mathrm{C}_{18} \mathrm{H}_{36} \mathrm{O}_{2}$ & 284 & -0.18 & Ethyl palmitate \\
\hline 2 & 14.83 & 2423828 & 308.5 & $\mathrm{C}_{20} \mathrm{H}_{36} \mathrm{O}_{2}$ & 308 & -0.16 & Ethyll linolenate \\
\hline 3 & 14.89 & 5411461 & 310.5 & $\mathrm{C}_{20} \mathrm{H}_{38} \mathrm{O}_{2}$ & 310 & -0.16 & Ethyl linoleate \\
\hline 4 & 15.12 & 359612 & 312.5 & $\mathrm{C}_{20} \mathrm{H}_{40} \mathrm{O}_{2}$ & 312 & -0.16 & Ethyl stearate \\
\hline 5 & 17.77 & 3836542 & 352.6 & $\mathrm{C}_{18} \mathrm{H}_{32} \mathrm{O}_{2}$ & 353 & 0.11 & Linoleic acid TMS \\
\hline 6 & 18.10 & 17168 & 350.6 & $\mathrm{C}_{18} \mathrm{H}_{30} \mathrm{O}_{2}$ & 352 & 0.4 & Linolenic acid TMS \\
\hline 7 & 20.41 & 18788155 & 372.7 & $\mathrm{C}_{27} \mathrm{H}_{48}$ & 372 & -0.19 & Cholestane \\
\hline 8 & 23.44 & 452445 & 486.9 & $\mathrm{C}_{29} \mathrm{H}_{50} \mathrm{O}$ & 484 & -0.6 & $\beta$-Sitosterol TMS \\
\hline 9 & 23.70 & 770310 & 485.8 & $\mathrm{C}_{29} \mathrm{H}_{48} \mathrm{O}$ & 485 & -0.16 & Stigmasterol TMS \\
\hline 10 & 24.37 & 12299199 & 472.9 & $\mathrm{C}_{28} \mathrm{H}_{48} \mathrm{O}$ & 472 & -0.19 & Campesterol TMS \\
\hline 11 & 25.99 & 324939 & - & - & - & - & Unknown \\
\hline
\end{tabular}

\subsection{Liquid Chromatographic Analysis of Phenolic Compounds}

In the chromatographic profile (Figure 3), 16 small peaks were detected in the range from 100 to $700 \mathrm{~m} / \mathrm{z}$. These peaks indicated that there are at least 16 possible phenolic compounds existing in the GSO. Additional data on the high-performance liquid chromatography-single quadrupole electrospray ionization/mass spectrometry (HPLC-ESI/MS) analysis, including retention times, molecular ions and important fragment ions for tentative compounds, are presented in Figure S3a. Authentic standards, including gallic acid, catechin, tannic acid, rutin, isoquercetin, hydroquinine, eriodictyol and quercetin, were analyzed and used as database, and are presented in Figure S3b. In comparison with the standards, 
catechin, isoquercetin, eriodictyol and quercetin were detected in the GSO, while gallic acid, tannic acid, rutin and hydroquinine would not be found.

In illustration, the fragmentations of phenolic compounds in the positive ion mode, eluted at retention times of 9.47, 10.11, 12.64, 13.48, 14.02, 14.69, 16.11, 21.04, 29.53, 31.15, 32.32, 32.99, 34.47 and $35.09 \mathrm{~min}$, were characterized as quinic acid, $\mathrm{O}$-caffeoylquinic acid or chlorgenic acid, catechin, apigenin-4-O-glycoside, ellagic acid-O-methoxyglucoside, dicaffeic acid, isoquercetin, $\mathrm{O}$-caffeoylquinic acid derivative, ellagic acid, eriodictyol, luteolin-7-O-rutinoside, quercetin, caffeoyl-glycosides or cinnamoyl glycosides, and di-O-caffeoyquinic acid, respectively (Table 3). However, two other compounds which were eluted at 17.22 and $25.84 \mathrm{~min}$ were not able to be identified. In term of limitation, the database library was not available for identification of the targeted compounds, and it is likely that the HPLC-ESI/MS analysis lacked sensitivity.

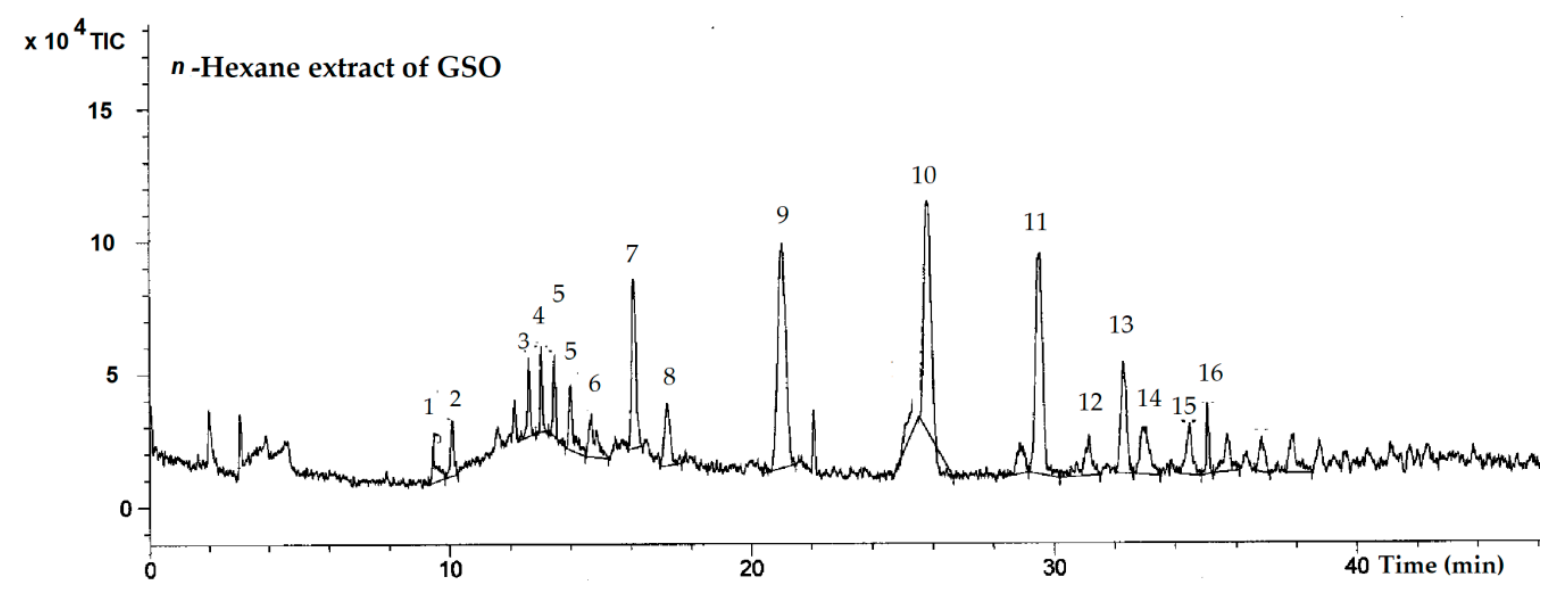

Figure 3. Total ion counts of HPLC-ESI/MS analysis for GSO. Peak identities are numbered in Table 3. 
Table 3. HPLC-ESI/MS identification of phenolic compounds for guava seed oil.

\begin{tabular}{|c|c|c|c|c|c|c|c|c|}
\hline $\begin{array}{l}\text { Peak } \\
\text { No. }\end{array}$ & $\begin{array}{c}\mathrm{T}_{\mathrm{R}} \\
(\mathrm{min})\end{array}$ & TIC & $\begin{array}{l}\text { Exact Mass } \\
(\mathrm{g} / \mathrm{mol})\end{array}$ & $\begin{array}{l}\text { Molecular } \\
\text { Formula }\end{array}$ & $\begin{array}{c}\text { Observed Mass } \\
(\mathrm{m} / \mathrm{z})\end{array}$ & Error $(\%)$ & Possible Constituents/Compounds & References \\
\hline 1 & 9.47 & 153000 & 192.1 & $\mathrm{C}_{7} \mathrm{H}_{12} \mathrm{O}_{6}$ & {$[\mathrm{M}-\mathrm{H}]^{+} 194.1$} & 1.03 & Quinic acid & [25] \\
\hline 2 & 10.11 & 174000 & 354.3 & $\mathrm{C}_{16} \mathrm{H}_{18} \mathrm{O}_{9}$ & {$[\mathrm{M}-\mathrm{H}]^{+} 354.9$} & 0.17 & O-Caffeoylquinic acid & {$[25,26]$} \\
\hline 3 & 12.64 & 185000 & 290.3 & $\mathrm{C}_{15} \mathrm{H}_{14} \mathrm{O}_{6}$ & {$[\mathrm{M}-\mathrm{H}]^{+} 298.9$} & 2.88 & Catechin & Authentic standard \\
\hline 4 & 13.48 & 152000 & 432.1 & $\mathrm{C}_{21} \mathrm{H}_{20} \mathrm{O}_{10}$ & {$[\mathrm{M}-\mathrm{H}]^{+} 433.3$} & 0.23 & Apigenin-4-O-glycoside & {$[27,28]$} \\
\hline 5 & 14.02 & 254000 & 496.2 & $\mathrm{C}_{21} \mathrm{H}_{21} \mathrm{O}_{14}$ & {$[\mathrm{M}-\mathrm{H}]^{+} 497.2$} & 0.2 & Ellagic acid-O-methoxyglucoside & {$[29,30]$} \\
\hline 6 & 14.69 & 254000 & 342.3 & $\mathrm{C}_{18} \mathrm{H}_{14} \mathrm{O}_{7}$ & {$[\mathrm{M}-\mathrm{H}]^{+} 342.9$} & 0.15 & Dicaffeic acid & {$[26,28]$} \\
\hline 7 & 16.11 & 649000 & 464.1 & $\mathrm{C}_{15} \mathrm{H}_{10} \mathrm{O}_{7}$ & {$[\mathrm{M}-\mathrm{H}]^{+} 454.3$} & 2.15 & isoquercetin & Authentic standard \\
\hline 8 & 17.22 & 318000 & Unknown & Unknown & ND & ND & Unknown & - \\
\hline 9 & 21.04 & 160000 & 452.1 & Unknown & {$[\mathrm{M}-\mathrm{H}]^{+} 453.2$} & 0.27 & O-Caffeoylquinic acid derivative & [25] \\
\hline 10 & 25.84 & 129000 & Unknown & Unknown & {$[\mathrm{M}-\mathrm{H}]^{+} \mathrm{ND}$} & ND & Unknown & - \\
\hline 11 & 29.53 & 138000 & 302.2 & $\mathrm{C}_{14} \mathrm{H}_{6} \mathrm{O}_{8}$ & {$[\mathrm{M}-\mathrm{H}]^{+} 302.5$} & 0.1 & Ellagic acid & {$[31,32]$} \\
\hline 12 & 31.15 & 306000 & 288.25 & $\mathrm{C}_{15} \mathrm{H}_{12} \mathrm{O}_{6}$ & {$[\mathrm{M}-\mathrm{H}]^{+} 297.0$} & 2.95 & Eriodictyol & Authentic standard \\
\hline 13 & 32.32 & 543000 & 594.5 & $\mathrm{C}_{27} \mathrm{H}_{30} \mathrm{O}_{15}$ & {$[\mathrm{M}-\mathrm{H}]^{+} 595.5$} & 0.17 & Luteolin-7-O-rutinoside & [24] \\
\hline 14 & 32.99 & 379000 & 302.2 & $\mathrm{C}_{15} \mathrm{H}_{10} \mathrm{O}_{7}$ & {$[\mathrm{M}-\mathrm{K}]^{+} 340.3$} & 0.26 & Quercetin & Authentic standard \\
\hline 15 & 34.47 & 261000 & 382.0 & $\mathrm{C}_{17} \mathrm{H}_{18} \mathrm{O}_{10}$ & {$[\mathrm{M}-\mathrm{H}]^{+} 383.3$} & 0.34 & Caffeoyl-glycosides or cinnamoyl glycosides & [26] \\
\hline 16 & 35.09 & 180000 & 516.45 & $\mathrm{C}_{25} \mathrm{H}_{24} \mathrm{O}_{12}$ & {$[\mathrm{M}-\mathrm{H}]^{+} 517.3$} & 0.16 & di-O-Caffeoyquinic acid & [26] \\
\hline
\end{tabular}




\subsection{Free-Radical Scavenging Activity}

It was determined that GSO treatment showed an inhibitory effect on 1,1-diphenyl-2-picrylhydrazyl radical $\left(\mathrm{DPPH}^{\bullet}\right)$ generation in a concentration-dependent manner $(6.25-1000 \mathrm{mg} / \mathrm{mL})$. In this determination, the inhibition by GSO was almost complete at the concentration of $200 \mathrm{mg} / \mathrm{mL}$ or 28.74 $\mu$ g 6-hydroxy-2,5,7,8-tetramethylchroman-2-carboxylic acid (Trolox) equivalent (TE)/mL. In comparison, Trolox and $\alpha$-tocopherol were found to be even more effective in scavenging DPPH ${ }^{\bullet}$ than GSO, and in this determination the inhibition levels were dependent upon the concentrations of 20-60 $\mu \mathrm{g} / \mathrm{mL}$, and were complete above $60 \mu \mathrm{g} / \mathrm{mL}$ (Figure 4). In addition, GSO was measured at a half maximal effective concentration $\left(\mathrm{EC}_{50}\right.$ ) against Trolox, and the results revealed that GSO decreased the initial $\mathrm{DPPH}^{\bullet}$ concentration by $50 \%$ at a concentration value of $139 \mathrm{~g} \mathrm{GSO} / \mathrm{g}\left[\mathrm{DPPH}{ }^{\bullet}\right]$.

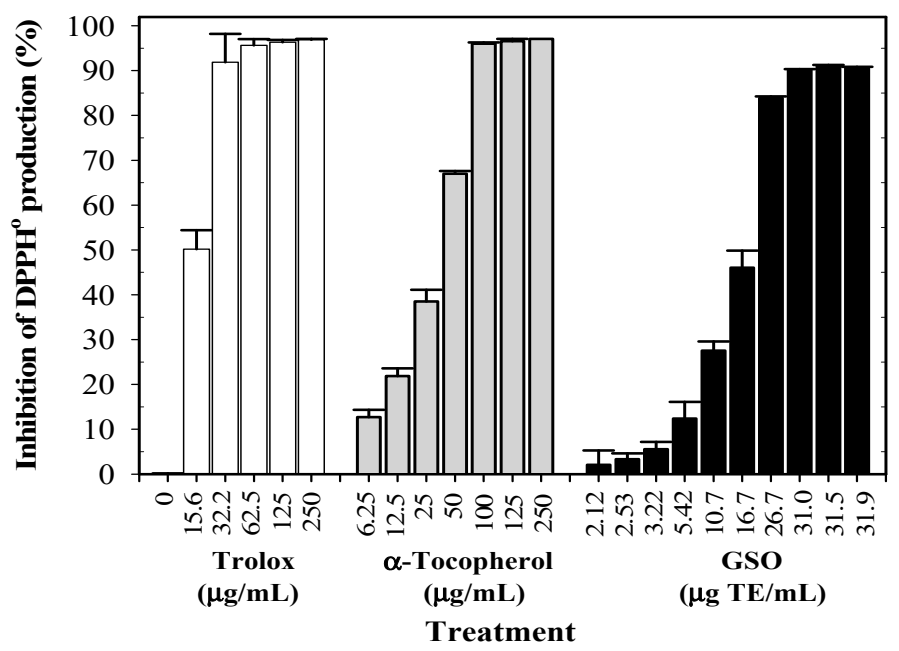

Figure 4. Inhibition of 1,1-diphenyl-2-picrylhydrazyl radical ( $\mathrm{DPPH}^{\bullet}$ ) generation by guava seed oil, $\alpha$-tocopherol and Trolox. Data obtained from two independent experiments performed in triplicate are expressed as mean \pm standard deviation (SD).

Furthermore, GSO and $\alpha$-tocopherol were found to reduce reactive oxygen species (ROS) levels in human hepatocellular carcinoma (HepG2) cells, in a concentration-dependent manner $(p<0.05$ at 100 and $200 \mu \mathrm{g} / \mathrm{mL}$ ), when compared with non-treated cells. In this determination, GSO was found to be less effective at equal concentrations of $\alpha$-tocopherol (Figure 5 , left). Similarly, both GSO and $\alpha$-tocopherol dose-dependently suppressed the elevation of ROS levels in hydrogen peroxide $\left(\mathrm{H}_{2} \mathrm{O}_{2}\right.$ )-induced human neuroblastoma (SH-SY5Y) cells, for which the degree of inhibition was significant at $200 \mu \mathrm{g} / \mathrm{mL}$ of $\alpha$-tocopherol (Figure 5, right). It is likely that antioxidant compounds, including polar phenolic compounds (such as quinic acid and its derivatives, chlorogenic acid and its derivatives, and hydrolysable tannins), phytosterols (such as stimasterol and campesterol) and lipids (such as linoleic acid), exist as a consequence of GSO-protected oxidative stress in HepG2 and SH-SY5Y cells, consequently preventing neurodegenerative diseases. 

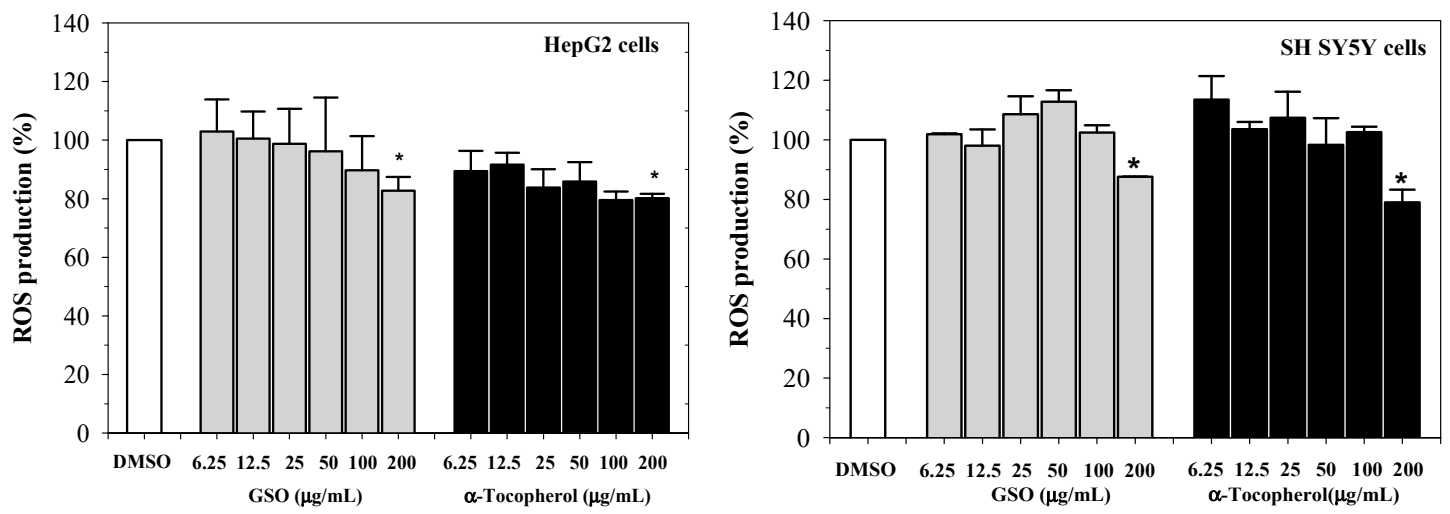

Figure 5. Free-radical scavenging activity of reactive oxygen species in hydrogen peroxide-induced human hepatocellular carcinoma (HepG2) and neuroblastoma (SH-SY5Y) cells by guava seed oil and $\alpha$-tocopherol. Data obtained from two independent experiments performed in triplicate are expressed as mean \pm SD values. ${ }^{*} p<0.05$ when compared to non-treated cells. Abbreviations: $\mathrm{GSO}=$ guava seed oil, $\mathrm{ROS}=$ reactive oxygen species.

\subsection{Bioavailability of Serum Lipids in GSO-Fed Rats}

As shown in Table 4, serum levels of total cholesterol did not change significantly in the rats that had been fed DI (control), CO (reference oil) (30 g linoleic acid equivalent (LAE)/kg) and GSO (6 and $30 \mathrm{~g} \mathrm{LAE} / \mathrm{kg}$ ) for $90 \mathrm{~d}$, irrespective of gender. The serum cholesterol levels were neither influenced by the GSO and CO feeding nor GSO doses when compared with DI. Throughout the study, serum triglyceride levels were found to be higher in male rats than in female rats $(p>0.05)$ among all gender-based rat groups, while they were not different in mixed gender groups and tended to decrease over the course of the study. For $90 \mathrm{~d}$, serum triglyceride levels were decreased to a greater degree in the CO $(30 \mathrm{~g} \mathrm{LAE} / \mathrm{kg})$ treatment $(\Delta 28.5 \mathrm{mg} / \mathrm{dL})$ and the GSO $(30 \mathrm{~g} \mathrm{LAE} / \mathrm{kg})$ treatment $(\Delta 16.5 \mathrm{mg} / \mathrm{dL})$ than in the DI group $(\Delta 7.6 \mathrm{mg} / \mathrm{dL})(P<0.05)$, while serum triglyceride levels were found to have increased in the GSO $(6 \mathrm{~g} \mathrm{LAE} / \mathrm{kg})$ treatment $(\Delta 24.3 \mathrm{mg} / \mathrm{dL})$.

Here, we used a very sensitive high-performance liquid chromatography/fluorescence detection (HPLC/FLD) method, together with alcoholic acid hydrolysis, for the quantitation of derivatized fatty acids. Authentic fatty acids, including $\alpha$-linolenic acid (ALA), arachidonic acid (AA), palmitoleic acid (PLA), linoleic acid (LA), stearic acid (SA) and oleic acid (OA) (100 $\mu \mathrm{M}$ each), were used to calibrate the column, on which they were positioned separately at $\mathrm{T}_{R}$ of 19.90, 24.71, 26.72, 30.24, 46.46 and $49.66 \mathrm{~min}$, respectively (Figure $S 4$ ). Using the specific $T_{R}$ of the standard fatty acids, serum concentrations of PLA, OA, SA, LA, ALA and AA were calculated, and are shown in Table 5. The findings presented in Table 5 show very low or undetectable concentrations of serum PLA and ALA in all rat groups. Feeding LA-rich CO and GSO (30 g LAE $/ \mathrm{kg}$ ) for $90 \mathrm{~d}$ did not increase serum levels of LA, but did show a tendency to decrease them when compared to the control DI. Importantly, there was a tendency of CO (30 g LAE $/ \mathrm{kg})$ and GSO (30 g LAE/ $/ \mathrm{kg})$ feeding to significantly decrease the serum levels of $\mathrm{OA}, \mathrm{SA}$ and AA in all rat groups (mixed genders), for which the GSO was more efficient than the $\mathrm{CO}$ when compared with the DI control group. In addition, GSO $(30 \mathrm{~g} \mathrm{LAE} / \mathrm{kg})$ was found to have lowered the serum SA level to a greater degree than GSO $(6 \mathrm{~g} \mathrm{LAE} / \mathrm{kg})(p<0.05)$. These results imply that GSO consumption potentially lowers the plasma triglyceride levels, and can modulate the serum levels of fatty acids (e.g., stearic, oleic and arachidonic acids), similarly to CO consumption at an equal concentration. 
Table 4. Serum levels of total cholesterol and triglyceride from rats ( 5 male and 5 female each) treated with deionized water, corn oil (30 $\mathrm{g}$ LAE/kg) and guava seed oil (6 g and $30 \mathrm{~g} \mathrm{LAE} / \mathrm{kg}$ ) for 90 days. Data are expressed as individual and mean \pm SD values. ${ }^{\&} p<0.05$ when compared with the level at the baseline (day 0 ).

\begin{tabular}{|c|c|c|c|c|c|c|c|c|c|c|c|c|c|}
\hline \multirow{2}{*}{ Serum Lipids } & \multirow{2}{*}{ Time } & \multicolumn{3}{|c|}{ DI } & \multicolumn{3}{|c|}{ CO (30 g LAE $/ \mathrm{kg})$} & \multicolumn{3}{|c|}{ GSO (6 g LAE/kg) } & \multicolumn{3}{|c|}{ GSO (30 g LAE/kg) } \\
\hline & & $5 \mathrm{M}$ & $5 \mathrm{~F}$ & $5 \mathrm{M}, 5 \mathrm{~F}$ & $5 \mathrm{M}$ & $5 \mathrm{~F}$ & $5 \mathrm{M}, 5 \mathrm{~F}$ & $5 \mathrm{M}$ & $5 \mathrm{~F}$ & $5 \mathrm{M}, 5 \mathrm{~F}$ & $5 \mathrm{M}$ & $5 \mathrm{~F}$ & $5 \mathrm{M}, 5 \mathrm{~F}$ \\
\hline Total cholesterol & Day 0 & $64.4 \pm 8.0$ & $61.8 \pm 11.5$ & $63.1 \pm 9.4$ & $65.6 \pm 10.7$ & $66.2 \pm 6.9$ & $65.9 \pm 8.5$ & $67.4 \pm 11.2$ & $72.6 \pm 11.6$ & $70.0 \pm 11.1$ & $62.4 \pm 4.2$ & $69.2 \pm 12.7$ & $65.8 \pm 9.6$ \\
\hline$(\mathrm{mg} / \mathrm{dL})$ & Day 90 & $66.8 \pm 13.5$ & $51.8 \pm 8.5$ & $59.3 \pm 13.3$ & $62.2 \pm 4.8$ & $65.4 \pm 6.1$ & $63.8 \pm 5.5$ & $72.8 \pm 16.4$ & $62.2 \pm 4.8$ & $67.5 \pm 12.7$ & $74.0 \pm 6.5$ & $62.6 \pm 10.1$ & $68.3 \pm 10.0$ \\
\hline$\underset{\text { (mg/dL) }}{\text { Triglyceride }}$ & $\begin{array}{l}\text { Day } 0 \\
\text { Day } 90\end{array}$ & $\begin{array}{l}87.0 \pm 24.2 \\
66.2 \pm 19.4\end{array}$ & $\begin{array}{c}33.2 \pm 8.2 \\
38.8 \pm 11.7\end{array}$ & $\begin{array}{l}60.1 \pm 33.1 \\
52.5 \pm 20.9\end{array}$ & $\begin{array}{c}100.4 \pm 24.6 \\
39.8 \pm 6.4\end{array}$ & $\begin{array}{l}44.8 \pm 4.3 \\
48.4 \pm 7.9\end{array}$ & $\begin{array}{c}72.6 \pm 33.7 \\
44.1 \pm 8.1 \&\end{array}$ & $\begin{array}{c}70.0 \pm 17.4 \\
118.6 \pm 45.1\end{array}$ & $\begin{array}{c}41.8 \pm 10.0 \\
39.8 \pm 6.4\end{array}$ & $\begin{array}{l}55.9 \pm 20.0 \\
79.2 \pm 51.4\end{array}$ & $\begin{array}{l}89.4 \pm 34.2 \\
77.4 \pm 20.2\end{array}$ & $\begin{array}{l}60.8 \pm 9.9 \\
39.8 \pm 9.8\end{array}$ & $\begin{array}{c}75.1 \pm 28.1 \\
58.6 \pm 24.8 \&\end{array}$ \\
\hline
\end{tabular}

Abbreviations: $\mathrm{CO}=$ corn oil, $\mathrm{DI}=$ deionized water, $\mathrm{GSO}=$ guava seed oil, $\mathrm{LAE}=$ linoleic acid equivalent, $\mathrm{TC}=$ total cholesterol, $\mathrm{TG}=$ triglyceride.

Table 5. Levels of fatty acids of serum obtained from rats treated with deionized water, corn oil and guava seed oil for 90 days. Data are expressed as mean \pm SD values. ${ }^{*} p<0.05$ when compared with deionized water; ${ }^{\#} p<0.05$ when compared with the levels at a lower concentration.

\begin{tabular}{|c|c|c|c|c|c|c|c|c|c|c|c|c|}
\hline \multirow{2}{*}{$\begin{array}{l}\text { Fatty Acid } \\
\text { Levels }\end{array}$} & \multicolumn{3}{|c|}{ DI } & \multicolumn{3}{|c|}{$\mathrm{CO}(30 \mathrm{~g} \mathrm{LAE} / \mathrm{kg})$} & \multicolumn{3}{|c|}{ GSO (6 g LAE/kg) } & \multicolumn{3}{|c|}{ GSO (30 g LAE/kg) } \\
\hline & $5 \mathrm{M}$ & $5 \mathrm{~F}$ & $5 \mathrm{M}, 5 \mathrm{~F}$ & $5 \mathrm{M}$ & $5 \mathrm{~F}$ & $5 \mathrm{M}, 5 \mathrm{~F}$ & $5 \mathrm{M}$ & $5 \mathrm{~F}$ & $5 \mathrm{M}, 5 \mathrm{~F}$ & $5 \mathrm{M}$ & $5 \mathrm{~F}$ & $5 \mathrm{M}, 5 \mathrm{~F}$ \\
\hline $\begin{array}{l}\text { Palmitoleic acid } \\
(\mathrm{mg} / \mathrm{dL})\end{array}$ & $0.72 \pm 0.29$ & ND & $0.72 \pm 0.29$ & ND & ND & ND & ND & ND & ND & ND & ND & ND \\
\hline $\begin{array}{c}\text { Oleic acid } \\
(\mathrm{mg} / \mathrm{dL})\end{array}$ & $1.79 \pm 0.85$ & $1.00 \pm 0.35$ & $1.39 \pm 0.74$ & $0.57 \pm 0.19$ & $0.75 \pm 0.19$ & $0.66 \pm 0.20 *$ & $1.04 \pm 0.37$ & $0.61 \pm 0.16$ & $0.82 \pm 0.35 *$ & $0.54 \pm 0.17$ & $0.62 \pm 0.07$ & $0.58 \pm 0.13^{*}$ \\
\hline $\begin{array}{l}\text { Stearic acid } \\
(\mathrm{mg} / \mathrm{dL})\end{array}$ & $4.39 \pm 1.38$ & $2.55 \pm 0.77$ & $3.47 \pm 1.44$ & $1.57 \pm 0.65$ & $1.84 \pm 0.37$ & $1.71 \pm 0.52 *$ & $2.74 \pm 0.43$ & $1.38 \pm 0.25$ & $2.06 \pm 0.79 *$ & $1.37 \pm 0.22$ & $1.33 \pm 0.15$ & $1.35 \pm 0.18^{*, \#}$ \\
\hline $\begin{array}{l}\text { Linoleic acid } \\
\text { (mg/dL) }\end{array}$ & $1.70 \pm 0.66$ & $0.90 \pm 0.31$ & $1.30 \pm 0.64$ & $0.97 \pm 0.41$ & $1.41 \pm 0.37$ & $1.19 \pm 0.43$ & $1.05 \pm 0.35$ & $0.59 \pm 0.15$ & $0.82 \pm 0.35$ & $0.82 \pm 0.24$ & $0.78 \pm 0.11$ & $0.80 \pm 0.18$ \\
\hline $\begin{array}{c}\alpha \text {-Linolenic } \\
\text { acid (mg/dL) }\end{array}$ & ND & ND & ND & ND & ND & ND & ND & ND & ND & ND & ND & ND \\
\hline $\begin{array}{l}\text { Arachidonic } \\
\text { acid (mg/dL) }\end{array}$ & $0.74 \pm 0.20$ & $0.55 \pm 0.13$ & $0.64 \pm 0.19$ & $0.34 \pm 0.13$ & $0.40 \pm 0.06$ & $0.37 \pm 0.10 *$ & $0.48 \pm 0.10$ & $0.40 \pm 0.04$ & $0.44 \pm 0.08 *$ & $0.35 \pm 0.05$ & $0.43 \pm 0.13$ & $0.39 \pm 0.10 *$ \\
\hline
\end{tabular}




\section{Discussion}

Natural products derived from several parts, of plants including leaves, roots, bark, rhizome, stock, pulp and seeds, have provided unparalleled sources of chemical diversity that possess bioactive molecules of valuable interest. Polyunsaturated fatty acids (PUFA) are rich in tree-born seed oils, and have been claimed to be rich in lipophilic antioxidants that are highly susceptible to oxidation, possibly leading to the generation of rancid oil and secondary lipid peroxides. So far, hyphenated analytical methods, such as GC/MS and HPLC/MS, have been applied for the efficient detection and characterization of targeted molecules. Likewise, GC/MS is a sensitive method for the comprehensive characterization of volatile small molecules such as fatty acids. Predominantly, HPLC-ESI/MS and high performance liquid chromatography-electrospray ionization/mass spectrometry/mass spectrometry (HPLC-ESI/MS/MS)) are powerful analytical techniques, with high sensitivity and accuracy, that can be used to determine the compound profile of plant materials and natural products [33]. Moreover, HPLC-ESI-Q-TOF/MS provides higher resolution, faster speeds and less solvent consumption, leading to a rapid and sensitive characterization of certain unexpected natural products [34,35].

Our recent findings have shown that the hexane extract of GSO was abundant with linoleic acid (most abundant at $69.95 \%$ of total fatty acids), followed by oleic acid, palmitic acid, stearic acid, arachidic acid and $\alpha$-linolenic acid. Consistently, GSO (Psidium gaujava L.) extraction with $n$-hexane solvent revealed a high content of linoleic acid ( $60.03 \%$ of total fatty acids) as the main fatty acid component [18]. In comparison, petroleum ether extract of GSO gave a higher yield of linoleic acid (78.4\% of total fatty acids) [17], suggesting that both the method employed and the solvent administered can affect the different percentage yields of linoleic acid. In studies on lipids, reverse-phase HPLC-ESI/MS is a robust and popular technique that is commonly used. In the literature, xestoaminol C obtained from a Fiji sponge Xestospongia sp. was reported to be an extremely active agent against parasites and microbes [36]. Not surprisingly, eschscholtzxanthin, which is the predominant pigment carotenoid in poppy petals, was found in the hexane extracts of GSO [37]. In this study, we have detected the presence of certain possible lipids, including 4-hexyl-decanoic acid, sphinganine, 5S-hydroxyeicosatetraenoyl di-endoperoxide, didrovaltratum, sphingofungin $B$, 13,14-dihydro-19(R)-hydroxyprostaglandin E1, eschscholtzxanthin, tetradecan-3-one and xestoaminol $\mathrm{C}$, in GSO. Surprisingly, none of these compounds have ever been reported to be isolated in the hexane extracts of GSO, but some compounds have been described. For instance, 4-hexyl-decanoic acid (isopalmitic acid) is a natural major branch-chain saturated fatty acid that is present in the leaves of Abies pindrow, and probably produced as a lipophilic adsorbent during hexane extraction [38,39]. Interestingly, sphingoganin and sphingofungin, existing in natural seed oils, and xestoaminol C found in New Zealand Brown Alga Xiphophora chondrophylla, showed strong anti-candidiasis and anti-tubercular activities [4042]. Notably, Eschscholtzxanthin is one of the red pigment carotenoids that is synthesized in the leaves of several plants as a response to photoinhibitory conditions during winter acclimation and displays antioxidant activity [43]. Consistently, we have demonstrated the anti-leukemic and anti-plasmodium activities of GSO [24]. Recently, we reported that the hexane extract of GSO was abundant with $\alpha$-tocopherol $(23.0 \mathrm{mg} / \mathrm{kg}$ ) and $\beta$-tocotrienol $(70.5 \mathrm{mg} / \mathrm{kg})[17,44]$. With regard to potential health benefits, phytosterols could play an important role in facilitating certain biological activities such as free-radical scavenging and plasma lipid-modulating effects. Here, we have analyzed GSO and found the presence of certain phytosterols, such as $\beta$-sitosterol $(297.61 \mathrm{mg} / 100 \mathrm{~g})$, stigmasterol $(0.22 \mathrm{mg} / 100 \mathrm{~g})$, campesterol $(11.04 \mathrm{mg} / 100 \mathrm{~g})$, and other neutral lipids. In comparison, hexane extracts of Panax quinquefolium ginseng and Cajanus cajan seed oils contained phytosterols such as squalene, oxidosqualene, campesterol, stigmasterol, clerosterol, $\beta$-sitosterol, $\beta$-amyrin, $\delta(5)$-avenasterol, $\delta[5,24(25)]$-stigmasterol, lupeol, $\delta(7)$-sitosterol, $\delta(7)$-avenasterol, 24-methylenecycloartanol and citrostadienol $[45,46]$. Additionally, hexane extracts of Alyssum homolocarpum seed oil were abundant with $\beta$-sitosterol $(3.3 \mathrm{mg} / \mathrm{g})$ and campesterol $(0.86 \mathrm{mg} / \mathrm{g})$, which readily transverse the blood-brain barrier [47]. Moreover, a variety of phytosterols, and their contents in hexane-extractable seed oils derived from Cajanus cajan, nutmeg, white mustard, anise, coriander and caraway, have been demonstrated [46,48]. 
We have revealed that the hexane extracts of GSO contained a total phenolic content of $45.57 \pm 0.97 \mu \mathrm{g}$ gallic acid equivalent (GAE)/g of GSO [43]. In this research, the HPLC-ESI single quadrupole/MS combined with correlation analysis of measured versus predicted mass spectra was used to afford the rapid characterization of small organic molecules, particularly the phenolic compounds present in GSO. Possible compounds included quinic acid, chlorogenic acid, catechin, apigenin-4-O-glycoside, ellagic acid-O-methoxyglucoside, dicaffeic acid, isoquercetin, chlorogenic acid derivative, ellagic acid, eriodictyol, luteolin-7-O-rutinoside, quercetin, caffeoyl-glycosides or cinnamoyl-glycosides and di-O-caffeoyquinic acid. In the case presented here, some compounds were identified after being compared with corresponding compounds that had been previously identified in natural products. Nonetheless, ESI single quadrupole/MS has traditionally presented certain limitations, such as unavailable authentic compounds as references, an incomplete database library, less ability to observe compounds of low polarity, and low sensitivity and mass resolution for detection when compared with HPLC-ESI/MS/MS or HPLC-ESI-QTOF/MS. In addition, the raw mass spectrometry data showed that many fragments were difficult to isolate for interpretation. Evidently, caffeoylquinic acid (chlorogenic acid) isomers, quinic acid derivatives, di-O-caffeoylquinic acid and caffeoylquinic acid derivatives were found in different proportions in the extracts obtained from Prunus domestica, Salicornia gaudichaudiana, Galphimia glauca, Gymnaster koraiensis, Artemisia princeps Pampanini and Foeniculum vulgare Mill, depending on organic solvent extractions [49-55]. Additionally, apigenin, luteolin and their glycosides are acknowledged as the predominant phenolic compounds in the hexane extracts of plant seeds, and these exert strong antioxidant or free-radical scavenging abilities, or altogether effects [46,56-58]. It is likely that the chlorogenic acid, caffeic acid derivatives, apigenin and its glycosides, exhibit antioxidant, free-radical scavenging and anti-inflammatory effects, suggesting that GSO would be significantly beneficial for living cells and human health.

In fact, PUFA, tocopherols, tocotrienols, phytosterols and phenols are the most important natural antioxidants that are present in vegetable and seed oils. Hence, the hexane extracts of seed oils that possess anti-oxidative compounds can also exert free-radical scavenging properties. Among available antioxidant assays, the $\mathrm{DPPH}^{\bullet}$ scavenging assay is a simple colorimetric method that can be applied for the study in both hydrophobic (e.g., hexane extract) and hydrophilic environments. In this study, we found that GSO was able to decrease levels of DPPH${ }^{\bullet}$ in aqueous environments, and $\mathrm{H}_{2} \mathrm{O}_{2}$-induced oxidative stress in HepG2 and SH-SY5Y cells in a concentration-dependent manner, even though it was less efficient than the reference antioxidants Trolox (water-soluble vitamin E analogue) and $\alpha$-tocopherol, respectively. Obviously, GSO presented $\mathrm{EC}_{50}$ of the DPPH${ }^{\bullet}$ scavenging activity at a dose of $139 \mathrm{~g}$ oil $/ \mathrm{g}$ [DPPH${ }^{\bullet}$ ] or $19.97 \mu \mathrm{g} \mathrm{TE} / \mathrm{g}$ [DPPH${ }^{\bullet}$ ], which then exerted antioxidant activity. Similarly, the researchers have shown that GSO reduced the initial DPPH ${ }^{\bullet}$ concentration by $50 \%\left(\mathrm{EC}_{50}\right)$ at a dose of $12.9 \mathrm{~g} \mathrm{oil}_{\mathrm{g}}$ [DPPH${ }^{\bullet}$ ] [17], which is potentially more powerful than our experiments with GSO. However, our GSO experiments demonstrated a lower value of EC $_{50}$ than other oils extracted from walnuts, peanuts, almonds, hazelnuts and pistachio nuts [59]. Moreover, we have proposed that the hepato- and neuro-protective effects acknowledged in GSO would be mediated by active phytosterols and phenolic compounds, via scavenging radicals that are generated during the production of oxidative stress. Notably, antioxidant activity may occur as a result of the presence of hydrophobic compounds (e.g., carotenoids, tocopherols, tocotrienols and linoleic acid per se) [60-62], along with the polar phenolics [63] that are present in certain plant seed oils including GSO, as was observed in this study. Zhang and Liu have demonstrated that the extracts derived from millets (Setaria italic and Panicum miliaceum) contain chlorogenic acid, caffeic acid, xanthophylls and zeaxanthin which could scavenge peroxyl radicals in 2,2-azobis-amidinopropane-induced HepG2 cells [64,65]. Likewise, the chlorogenic acid and di-O-caffeoylquinic acid present in plant extracts showed protective effects against oxidative stress-induced hepatic (HepG2), neuroblastoma (SH SY5Y), and nepheochromocytoma (P-12) cell damage $[53,54,66,67]$. Moreover, $\beta$-sitosterol and its glucoside obtained from the Gastrocotyle hispida extract exhibited $\mathrm{DPPH}^{\bullet}$-scavenging activity in a concentration-dependent manner [68]. Pretreatment with phytosterols, including $\beta$-sitosterol, daucosterol and pectolinarin obtained from Cirsium setidens 
and Aster scaber extracts, considerably decreased ROS levels in $\mathrm{H}_{2} \mathrm{O}_{2}$-induced neuroblastoma (SK-N-SH) cells [69].

Although GSO have exhibited important nutraceutical properties, such as high contents of linoleic acid, tocopherols and tocotrienols, anti-oxidation and wound healing effects, long-term consumption of the GSO may lead to dyslipidemia and increased levels of atherogenic index. Evidently, GSO $(30 \mathrm{~g} \mathrm{LAE} / \mathrm{kg})$ and $\mathrm{CO}(6 \mathrm{~g} \mathrm{LAE} / \mathrm{kg})$ treatments were found to lower the serum levels of triglycerides significantly, when compared to treatments without GSO. Similarly, the GSO and CO treatments could significantly decrease the serum levels of fatty acids, including oleic, stearic and arachidonic acids, when compared to treatments without GSO. In these treatments, the GSO (30 g LAE $/ \mathrm{kg}$ ) seemed to display a level of efficiency that was equal to the $\mathrm{CO}$ at an equal concentration but was greater than that of the GSO (6 g LAE $/ \mathrm{kg})$. From previous instances, long-term consumption of LA-rich corn oil and ALA-rich perilla oil revealed a trend of reducing serum triglyceride and cholesterol levels in rodents, when compared with the DI control. However, the consumption of flaxseed oil and CO did not change the serum cholesterol and triglyceride levels in humans. In the study, serum ALA was undetectable in all rat groups, while serum LA levels were lower in CO and GSO groups than in the DI group. A previous study has demonstrated that grape seed oil and corn oil, that were rich in linoleic acid or omega-6 fatty acids, tended to decrease serum cholesterol levels in rats [70]. Similarly, linoleic acid-rich niger seed oil was found to display a hypolipidemic effect through the facilitation of lipid transportation and metabolism, possibly lowering the risk of cardiovascular disease development [71]. Consistently, a combination diet of proteins, perilla seed oil, linoleic acid and $\alpha$-linolenic acid (per oral) was found to decrease plasma triglyceride and cholesterol levels in rats [72]. Importantly, the supplementation of caffeoylquinic acid (or chlorogenic acid), which is rich in the extracts obtained from chicory (Cichorium intybus) seeds and GSO, decreased levels of the triglyceride and atherogenic index, but increased levels of antioxidant capacity in the serum of rats that were fed with a high fructose/glucose diet [73]. Conversely, feeding rats with a berry seed oil-supplemented diet did not significantly influence the plasma levels of triglycerides, while the total cholesterol values, which included high-density and low-density lipoprotein fractions, were not changed [74]. The results suggest that GSO rich in $\alpha$-linoleic acid, phytosterols and chlorogenic acid could be utilized as a source of functional lipids, in the synthesis of essentially longer n-6 fatty acids, and the protection of oxidative stress-induced hepatocytes and neuronal cells.

\section{Materials and Methods}

\subsection{Chemicals and Reagents}

Arachidonic acid (AA), boron trifluoride $\left(\mathrm{BF}_{3}\right), 4$-bromomethyl-7-methoxycoumarin (Br-MMC), 18-crown-6, 2', 7'-dichlorodihydrofluorescein diacetate (DCFH-DA), 1,1-diphenyl-2-picrylhydrazyl (DPPH), Folin-Ciocalteu reagent, formic acid, hydrogen peroxide, linoleic acid (LA), $\alpha$-linolenic acid (ALA), oleic acid (OA), palmitic acid (PA), palmitoleic acid (PLA), phosphoric acid, stearic acid (SA), $\alpha$-tocopherol, and 6-hydroxy-2,5,7,8-tetramethylchroman-2-carboxylic acid (Trolox) were purchased from Sigma-Aldrich Company (St. Louis, MO, USA). Acetonitrile, acetic acid, ethanol, ethyl acetate, $n$-hexane, heptadecanoic acid, $n$-heptane, isopropanol, methanol, n-pentane (the highest pure HPLC grade), $N$-methyl- $N$-trimethylsilyltrifluoroacetamide (MSTFA, LiChropur ${ }^{\mathrm{TM}}$, purity $\geq 98.5 \%$ ) and deionized water (DI) (Milli-DI ${ }^{\circledR}$, Resistivity at $25^{\circ} \mathrm{C}>1 \mathrm{M} \Omega \cdot \mathrm{cm}$ ) were purchased from Merck Chemical Company (Merck KGaA, Darmstadt, Germany). Dulbecco's modified Eagle medium (DMEM), Ham's F12 Nutrient, fetal bovine serum (FBS), penicillin-streptomycin (10,000 U/L) and trypsin-ethylene diamine tetra acetic acid (trypsin-EDTA) were purchased from Gibco Technologies (Thermo Fisher Scientific, Waltham, MA, United States). Corn oil (CO) (density 0.91-0.93 g/mL, compositions of 2-3 g SA, 11-13 mg PA, 25-31 g OA, $59 \mathrm{~g}$ LA, $1 \mathrm{~g}$ ALA, $0.3 \mathrm{~g}$ trans-fats and $14.3 \mathrm{mg} \alpha$-tocopherol in $100 \mathrm{~g}$ of oil) was purchased from a supermarket that was located in the city of Chiang Mai. 


\subsection{Preparation of GSO Extract}

Dried guava seeds (P. guajava var Pan See Tong) $(200 \mathrm{~g})$ were ground and extracted with $n$-hexane $\left(1000 \mathrm{~mL}\right.$ ) in a Soxhlet apparatus (boiling point in the range of $60-80^{\circ} \mathrm{C}$ ) for $8 \mathrm{~h}$. The extract was then filtered through a Buchner funnel with Whatman's No. 1 filter paper and concentrated at $60^{\circ} \mathrm{C}$ using a rotatory evaporator [75]. The GSO obtained was decolorized with activated charcoal and stored in a plastic container in the dark at $4{ }^{\circ} \mathrm{C}$ for further study. From the chromatographic analyses, we found that the GSO contained linoleic acid, palmitic acid and oleic acid $(69.95 \%, 6.14 \%$ and $10.47 \%$ of total fatty acids, respectively), with a n3/n6 ratio of $1: 224 ; \alpha$-tocopherol $(23.0 \mathrm{mg} / \mathrm{kg}) ; \beta$-tocopherol $(1.5 \mathrm{mg} / \mathrm{kg}) ; \gamma$-tocopherol $(1.4 \mathrm{mg} / \mathrm{kg}) ; \beta$-tocotrienol $(70.5 \mathrm{mg} / \mathrm{kg}) ; \delta$-tocotrienol $(17.4 \mathrm{mg} / \mathrm{kg})$ and $\gamma$-tocotrienol $(4.0 \mathrm{mg} / \mathrm{kg})[24]$.

\subsection{High-Performance Liquid Chromatography-Electrospray Ionization-Quadrupole Time-of-Flight/Mass Spectrometry for Lipids}

GSO was analyzed for its polar phenolic compounds at the Central Laboratory, Faculty of Agriculture, Chiang Mai University, Chiang Mai, Thailand, using the HPLC-ESI-QTOF/MS method that was established by $\mathrm{Gu}$ and colleagues with slight modifications [35]. The HPLC instrument was equipped with an ESI-QTOF/MS machine (Agilent Acquisition SW version 6200 series TOF/6545 series LC/Q-TOF), QTOF Firmware Version 25.698 (Agilent Technologies, Santa Clara, CA, USA). Mobile phase A (acetonitrile) and mobile phase B $\left(0.1 \%\right.$ formic acid) were degassed at $25{ }^{\circ} \mathrm{C}$ for $15 \mathrm{~min}$. The GSO $(20 \mathrm{mg})$ was constituted in $1.0 \mathrm{~mL}$ of the A:B mixture $(1: 1, v / v)$, filtered using a syringe filer (polyvinylidene fluoride type, $0.45 \mu \mathrm{m}$ pore size, Millipore, MA, USA) and put into HPLC vials. The flow rate was set to be $0.35 \mathrm{~mL} / \mathrm{min}$, the injection volume was measured at $10 \mu \mathrm{L}$ for each sample, and the running time was $60 \mathrm{~min}$. Chromatographic separation was carried out on a column (InfinityLab Poroshell 120 EC-C18 type, $2.1 \mathrm{~mm} \times 100 \mathrm{~mm}, 2.7 \mu \mathrm{m}$, Agilent Technologies, Santa Clara, CA, USA) that was regulated thermally at $40^{\circ} \mathrm{C}$. The ESI-MS/MS spectra were recorded using the Agilent Q-TOF mass spectrometer (Agilent Technologies, Santa Clara, CA, USA). In the MS system, nitrogen gas nebulization was set at 45 pounds per inch ${ }^{2}$ with a flow rate of $5 \mathrm{~L} / \mathrm{min}$ at $300{ }^{\circ} \mathrm{C}$, and the sheath gas was set at $11 \mathrm{~L} / \mathrm{min}$ at $250{ }^{\circ} \mathrm{C}$. In addition, the capillary and nozzle voltage values were set at $3.5 \mathrm{kV}$ and $500 \mathrm{~V}$, respectively. A complete mass scan was conducted as a mass to charge ratio $(\mathrm{m} / \mathrm{z})$ ranging from 200 to 3200 . All the operations, acquisition and analysis of the data were monitored using Agilent LC-Q-TOF-MS MassHunter Acquisition Software Version B.04.00 (Agilent Technologies, Santa Clara, CA, USA) "Find by Be" algorithm to generate a list of accurate mass matches-compounds. Peak identification was performed in positive modes using the library database, and the identification scores were further selected for characterization and $m / z$ verification.

\subsection{Trimethylsilylation Derivatization-Gas Chromatography/Mass Spectrometry of Phytosterols}

\subsubsection{Derivatization}

The trimethylsilyl (TMS) derivatization-GC/MS of phytosterols for GSO was performed at the Central Laboratory (North Branch), Department of Land Development, Ministry of Agriculture and Cooperation, Chiang Mai, Thailand using the method established by Lee et al. with slight modifications [76]. Briefly, GSO $(100 \mu \mathrm{L})$ was evaporated to dryness under the nitrogen stream. The dried residue was re-dissolved in $1 \%$ pyridine in ethyl acetate $(40 \mu \mathrm{L})$ and MSTFA $(100 \mu \mathrm{L})$, and derivatized at $80^{\circ} \mathrm{C}$ for $30 \mathrm{~min}$. After cooling, the resulting solution was diluted with $0.4 \mathrm{~mL}$ of ethyl acetate and $60 \mu \mathrm{L}$ of cholestane (internal standard). A 4- $\mu \mathrm{L}$ aliquot of the resulting solution was directly injected into the GC/MS system. All of the derivatives were analyzed using GC-MS scan mode.

\subsubsection{Gas Chromatography/Mass Spectrometry}

GC-MS analysis was performed in full scan mode on the GC system (Agilent Technologies Model $6890 \mathrm{~N}$, Deutschland, GmbH, Waldbronn, Germany) that was directly coupled to the MS detector 
(Agilent Technologies Model 5973 inert, Palo Alto, CA, USA). Chromatographic separation was performed using a capillary column (DB-5MS, a dimension of $30 \mathrm{~m} \times 0.25 \mathrm{~mm}, 0.25 \mu \mathrm{m}$ film thickness, an Agilent J\&W Scientific (Folsom, CA, USA). Ultra-high purity helium was used as the carrier gas at a flow rate of $1.5 \mathrm{~mL} / \mathrm{min}$, with an inlet temperature $270^{\circ} \mathrm{C}$ and an auxiliary temperature of $280{ }^{\circ} \mathrm{C}$, for a running time of $35 \mathrm{~min}$. The sample solution was injected in split mode (split ratio 10:1) at $280{ }^{\circ} \mathrm{C}$. The electrospray ionization (ESI) energy was set at $70 \mathrm{eV}$. For the single quadrupole MS system, the temperatures of the ion source and the interface were set at $150{ }^{\circ} \mathrm{C}$ and $230{ }^{\circ} \mathrm{C}$, respectively. The mass scan ranged from 40 to $500 \mathrm{~m} / \mathrm{z}$. The selected ion monitoring (SIM) mode was set at 272 , 382,394 and $486 \mathrm{~m} / z$ for TMS-derivatized sterols, while the scanned mode was set in a range of 40 to $500 \mathrm{~m} / \mathrm{z}$ for TMS-derivatized unknown values. The oven temperature was programmed as follows: $80{ }^{\circ} \mathrm{C}$ (held for $3 \mathrm{~min}$ ), ramped to $110^{\circ} \mathrm{C}$ at $10^{\circ} \mathrm{C} / \mathrm{min}$ (held for $5 \mathrm{~min}$ ), increased to $190{ }^{\circ} \mathrm{C}$ (held for $3 \mathrm{~min}$ ), ramped to $220^{\circ} \mathrm{C}$ at $10{ }^{\circ} \mathrm{C} / \mathrm{min}$ (held for $4 \mathrm{~min}$ ), and increased to $280{ }^{\circ} \mathrm{C}$ at $15{ }^{\circ} \mathrm{C} / \mathrm{min}$ (held for $13 \mathrm{~min})$. In the phytosterol groups, $\beta$-stigmasterol, sitosterol, sitostanol and campesterol were identified using authentic reference standards. In addition, the mass fragments of the analytes were compared with the data of known compounds using a comprehensive mass-spectral library (Wiley version 7.0, www.wiley.com) for identification of the targeted molecules. In terms of method validation, the limit of detection (LOD) was $0.5 \mathrm{mg} / \mathrm{kg}$ (ppm), the limit of quantitation (LOQ) was $1.20 \mathrm{mg} / \mathrm{kg}$ (ppm), and the recovery value was $70-110 \%$.

\subsection{High-Performance Liquid Chromatography-Electrospray Ionization/Mass Spectrometry of Phenolic Compounds}

Qualitative analysis of phenolic compounds was carried out at the Central Laboratory (North Branch), Department of Land Development, Ministry of Agriculture and Cooperation, Chiang Mai using the HPLC/MS method established by Cuyckens and colleagues with slight modifications [77]. The HPLC system (Agilent Technologies 1100 Series, Deutschland GmbH, Waldbronn, Germany) consisted of a quaternary pump (G1311A), an online vacuum degasser (G1322A), an autosampler (G1313A), a thermostated column compartment (G1316A) and a photodiode array (PDA) detector (G1315A). The outlet of the PDA was coupled directly to the atmospheric pressure ESI interface of the mass spectrometer (MS) detector (Agilent Technologies 1100 LC/MSD SL, Palo Alto, CA, USA) through a flow splitter (1:1). In further analysis, GSO $(20 \mathrm{mg})$ was constituted in $1.0 \mathrm{~mL}$ of the mixture of solvent A (acetonitrile) and solvent B (10 mM formate buffer $\mathrm{pH} 4.0)(1: 1, v / v)$ and filtered through a syringe filter (polytetrafluoroethylene membrane, $25 \mathrm{~mm}$ diameter, $0.45-\mu \mathrm{m}$ pore size, Corning ${ }^{\circledR}$ ) before being used, and was then injected $(20 \mu \mathrm{L})$ into the system. Chromatographic separation was carried out on a column (LiChroCART RP-18e, $150 \mathrm{~mm} \times 4.6 \mathrm{~mm}, 5 \mu \mathrm{m}$ particle size; Purospher STAR, Merck, Darmstadt, Germany) operated at $40{ }^{\circ} \mathrm{C}$. The mobile phases A and B were run at a flow rate of $1.0 \mathrm{~mL} / \mathrm{min}$ under the gradient program of $100 \% \mathrm{~B}(0 \% \mathrm{~A})$ for an initial period of $5 \mathrm{~min}, 0-20 \%$ A from 5 to $10 \mathrm{~min}, 20 \%$ A from 10 to $20 \mathrm{~min}, 20-40 \%$ A from 20 to $60 \mathrm{~min}, 40 \%$ A for $3 \mathrm{~min}$, and followed by an initial $100 \%$ B for $5 \mathrm{~min}$. PDA detection was set at $270 \mathrm{~nm}$. MS analysis was done in positive ESI mode, and spectra were acquired within the mass to charge ratio $(\mathrm{m} / \mathrm{z})$ ranging from 100 to 700. For the single quadrupole MS system, the ESI energy was set at $70 \mathrm{eV}$, while the temperatures of the ion source and the interface were set at $150{ }^{\circ} \mathrm{C}$ and $230{ }^{\circ} \mathrm{C}$, respectively. Nitrogen was used as the nebulizing, drying and collision gas. The capillary temperature was set to $320^{\circ} \mathrm{C}$, the nebulizer pressure was set to $60 \mathrm{psi}$, and the drying gas flow rate was set to $13 \mathrm{~L} / \mathrm{min}$. Capillary voltages were set to $3500 \mathrm{~V}$ (positive) and $150 \mathrm{~V}$ (negative). The oven temperature was programmed as follows: $80{ }^{\circ} \mathrm{C}$ (held for $3 \mathrm{~min}$ ), ramped to $110^{\circ} \mathrm{C}$ at $10^{\circ} \mathrm{C} / \mathrm{min}$ (held for $5 \mathrm{~min}$ ), increased to $190{ }^{\circ} \mathrm{C}$ (held for $3 \mathrm{~min}$ ), ramped to $220^{\circ} \mathrm{C}$ at $10^{\circ} \mathrm{C} / \mathrm{min}$ (held for $4 \mathrm{~min}$ ), and increased to $280^{\circ} \mathrm{C}$ at $15^{\circ} \mathrm{C} / \mathrm{min}$ (held for $13 \mathrm{~min}$ ). Accurate mass measurements were performed by the auto mass calibration method using an external mass calibration solution (ESI-L Low Concentration Tuning Mix; Agilent calibration solution B). Herein, the LOD, LOQ and recovery value were found to be $0.5 \mathrm{mg} / \mathrm{kg}, 1.20 \mathrm{mg} / \mathrm{kg}$ and $70-110 \%$, respectively. The chromatographic and mass spectrometric analyses and prediction of the chemical 
formula, including the exact mass calculation, were performed by Mass Hunter software version B.04.00 build 4.0.479.0 (Agilent Technology, Santa Clara, CA, USA). Available authentic phenolics $(1 \mathrm{mg} / \mathrm{mL}$ each) such as gallic acid, catechin, tannic acid, rutin, isoquercetin, hydroquinine, eriodictyol and quercetin were also analyzed and used as database. In addition, MS data were searched for in published literature repositories.

\subsection{Determination of Free-Radical Scavenging Activity}

Antioxidant activity of GSO was assayed using the $\mathrm{DPPH}^{\bullet}$-scavenging method [78,79]. Briefly, GSO $(0-1000 \mathrm{mg} / \mathrm{mL}$ ethyl acetate) or Trolox $(0-250 \mu \mathrm{g} / \mathrm{mL}$ ethanol $)$ was mixed in equal volumes with $0.2 \mathrm{mM} \mathrm{DPPH}^{\circ}$ solution and incubated at $25^{\circ} \mathrm{C}$ in the dark for $30 \mathrm{~min}$. The OD of the colored product was measured at $515 \mathrm{~nm}$ against the reagent blank. The percentage of free-radical scavenging activity was calculated by applying the following formula:

$$
\% \mathrm{DPPH}^{\bullet} \text { scavenging }=\left[1-\left(\mathrm{OD}_{\text {sample }}-\mathrm{OD}_{\text {blank sample }}\right) / \mathrm{OD}_{\text {control }}\right] \times 100
$$

The values of GSO and Trolox decreased the initial $\mathrm{DPPH}^{\bullet}$ concentration by $50 \%\left(\mathrm{EC}_{50}\right)$ and were calculated by graphically plotting the percentage of the remaining $\mathrm{DPPH}^{\bullet}$ concentrations [17].

In addition, cellular ROS scavenging activity was determined in human hepatocellular carcinoma (HepG2) and neuroblastoma (SH-SY5Y) cells by using the fluorescent dichlorofluorescein (DCF)-fluorometric method [80]. In principle, DCFH-DA substrate simply diffuses into the cells and is hydrolyzed by cellular esterase to produce $2^{\prime}, 7^{\prime}$-dichlorofluorescein (reduced), which will be subsequently oxidized by existing ROS to a green fluorescence DCF product. Fluorescence intensity (FI) is directly proportional to the amount of ROS in the cells.

In assay, HepG2 cells were cultured in DMEM supplemented with $10 \%$ FBS, penicillin G $(100 \mathrm{U} / \mathrm{mL})$ and streptomycin $(100 \mu \mathrm{g} / \mathrm{mL})$ at $37{ }^{\circ} \mathrm{C}$ in a humidified atmospheric $5 \% \mathrm{CO}_{2}$ incubator. The cells $\left(10^{4}\right.$ cells/well) were incubated with GSO or $\alpha$-tocopherol at concentrations of $0-200 \mu \mathrm{g} / \mathrm{mL}$, which were previously diluted with DMSO (control) for $24 \mathrm{~h}$ at $37^{\circ} \mathrm{C}$. Afterwards, the treated cells were incubated with a $10 \mu \mathrm{M}$ DCFH-DA solution at $37^{\circ} \mathrm{C}$ for $30 \mathrm{~min}$ and washed twice with PBS. After being challenged with $100 \mu \mathrm{M}$ hydrogen peroxide $\left(\mathrm{H}_{2} \mathrm{O}_{2}\right)$, kinetic FI was measured at wavelengths of $\lambda_{\mathrm{ex}} 485 \mathrm{~nm}$ and $\lambda_{\mathrm{em}} 530 \mathrm{~nm}$ using a flow cytometer (Guava ${ }^{\circledR}$ easyCyte, Merck, Darmstadt, Germany).

SH-SY5Y cell line was purchased from the American Type Culture Collection (ATCC ${ }^{\circledR}$ CRL2266 ${ }^{\mathrm{TM}}$, Manassa, VA, USA). Cells were cultured in DMEM and Ham's F12 Nutrient Mixture (ratio 1:1, by volume) supplemented with $20 \%(v / v)$ FBS, $100 \mathrm{U} / \mathrm{mL}$ penicillin and $100 \mu \mathrm{g} / \mathrm{mL}$ streptomycin, and maintained at $37^{\circ} \mathrm{C}$ in a $5 \% \mathrm{CO}_{2}$ incubator [81]. Similarly, SH-SY5Y cells $\left(1 \times 10^{4}\right.$ cells/well and viability $>80 \%$ ) were seeded in 96-well plates for $24 \mathrm{~h}$, then treated with GSO or $\alpha$-tocopherol $(12.5-200 \mu \mathrm{g} / \mathrm{mL})$ or DMSO for $24 \mathrm{~h}$ at $37^{\circ} \mathrm{C}$. Afterwards, the treated cells were incubated with $10 \mu \mathrm{M}$ DCFH-DA at $37^{\circ} \mathrm{C}$ for $30 \mathrm{~min}$, washed twice with PBS solution and challenged with $100 \mu \mathrm{M} \mathrm{H}_{2} \mathrm{O}_{2}$. The FI values were then measured at wavelengths of $\lambda_{\mathrm{ex}} 485 \mathrm{~nm}$ and $\lambda_{\mathrm{em}} 530 \mathrm{~nm}$ with 1-h kinetic mode using a flow cytometer (Guava ${ }^{\circledR}$ easyCyte, Merck, Darmstadt, Germany).

\subsection{Analysis Serum Lipids in Guava Seed Oil-Fed Rats}

The protocol for the study involving animals was approved by the Ethical Committee for Animal Studies of the Medical Faculty, Chiang Mai University (Protocol Number 43/2558). Wistar rats were randomly divided into 4 groups ( 5 male and 5 female rats in each group), and fed with a nutritionally-balanced commercial diet (No. C.P. 082, Perfect Companion Group Co. Ltd., Bangkok, Thailand) comprised of crude protein $24 \%$, fat $4.5 \%$, fiber $5 \%$, minerals (Ca $1.0 \%, \mathrm{Na} 0.20 \%, \mathrm{~K} 1.17 \%$, Mg 0.23\%, Mn 171 ppm, Cu 22 ppm, Zn 100 ppm, Fe 180 ppm, Se 0.1 ppm) and vitamins (A 20,000 IU/kg, D $4000 \mathrm{IU} / \mathrm{kg}$, E $100 \mathrm{mg} / \mathrm{kg}, B_{1} 5 \mathrm{mg} / \mathrm{kg}, B_{2} 20 \mathrm{mg} / \mathrm{kg}, B_{6} 20 \mathrm{mg} / \mathrm{kg}, B_{12} 0.036 \mathrm{mg} / \mathrm{kg}$, niacin $100 \mathrm{mg} / \mathrm{kg}$, folic acid $6 \mathrm{mg} / \mathrm{kg}$, biotin $0.4 \mathrm{mg} / \mathrm{kg}$, pantothenic acid $60 \mathrm{mg} / \mathrm{kg}$ ). The rats were orally administered with DI, $\mathrm{CO}$ [30 g linoleic acid equivalent (LAE)/kg], and GSO (6 g LAE and $30 \mathrm{~g} \mathrm{LAE} / \mathrm{kg}$ ) for $90 \mathrm{~d}$. Fasting 
blood was collected on days 0 and 90, and serum was separated for the analysis of total cholesterol and triglyceride levels using a Randox ${ }^{\circledR}$ automated analyzer (Randox Laboratories Ltd., County Antrim, United Kingdom) according to the manufacturer's instructions.

In addition, serum fatty acid levels were quantified using the high-performance liquid chromatography/fluorescence detection (HPLC/FLD) method [82]. With regard to the assay, serum $(100 \mu \mathrm{L})$ was firstly spiked with an internal standard of $5 \mathrm{mM}$ heptadecanoic acid $(20 \mu \mathrm{L})$, and then incubated with Dole's reagent (isopropanol: $n$-heptane: $2 \mathrm{M}$ phosphoric acid = 40:10:1 by volume) $(500 \mu \mathrm{L})$ at room temperature for 5-10 min. Secondly, the mixture was incubated with $n$-heptane $(200 \mu \mathrm{L})$ and water $(300 \mu \mathrm{L})$, and centrifuged at $1000 \times g$ for $5 \mathrm{~min}$. Thirdly, the upper-layer heptane extract (200 $\mu \mathrm{L})$ was aspirated, evaporated using nitrogen gas, and incubated with a derivatizing reagent $(200 \mu \mathrm{L})$ made of $10 \mathrm{mg}$ Br-MMC, $26.5 \mathrm{mg}$ 18-crown-6 and $100 \mathrm{mg}$ potassium carbonate in $10 \mathrm{~mL}$ of acetonitrile at $60{ }^{\circ} \mathrm{C}$ for $15 \mathrm{~min}$, in order to produce a fluorogenic methyl-7-methoxycoumarin fatty acid (MMC-FA) derivative. The derivative solution was passed through a $0.45 \mu \mathrm{m}$ nylon-membrane filter and analyzed using the HPLC/FLD system. The conditions included a column (C18 type, $4.6 \mathrm{~mm} \times 250 \mathrm{~mm}, 5 \mu \mathrm{m}$ particle size, Agilent Technologies, Santa Clara, California, United States), a mobile-phase solvent (acetonitrile:DI $=85: 15, v / v)$, a flow rate of $1.5 \mathrm{~mL} / \mathrm{min}$, fluorescence detection $\left(\lambda_{\mathrm{ex}} 325 \mathrm{~nm}, \lambda_{\mathrm{em}} 398 \mathrm{~nm}\right.$ ) and a data recorder/integrator using Millenium 32 HPLC Software (version 3.2, Waters Corporation, Milford, MA, USA, 2000). Serum fatty acid values were identified by comparison with the specific $\mathrm{T}_{\mathrm{R}}$ of the authentic fatty acids including $\alpha$-linolenic, arachidonic, palmitoleic, stearic and oleic acids. Concentrations of serum fatty acids were determined from the standard curves constructed from different concentrations.

\subsection{Statistical Analysis}

Data were analyzed using the SPSS program (IBM SPSS Statistics V 22.0, (IBM Coporation, Ormonk, NY, USA, 2013 shared license by Chiang Mai University) and are presented as mean \pm standard deviation (SD) or mean \pm standard error of mean (SEM) values. Statistical significance was determined using one-way analysis of variance (post-hoc $=$ Tukey-HSD). $p<0.05$ was considered significant.

\section{Conclusions}

In conclusion, our studies show that guava seed oil (Psidium guajava) contains phenolic compounds and phytosterols, which are free-radical scavenging and have protective effects against cell damage in hepatic- and neuro-cell lines. Chronic oral administration to rats at high doses was associated with significant lowering of plasma triglycerides, without alteration in serum cholesterol, similar to that seen with corn oil administration at the same dose. The potential clinical relevance of the findings merits further investigation.

Supplementary Materials: The following are available online. Figure S1: HPLC-ESI-QTOF/MS for lipids of GSO. Figure S2: GC/MS for phytosterols of GSO. Figure S3: (a) LC-ESI/MS for phenolics of GSO; (b) LM/MS for authentic phenolics. Figure S4: HPLC FLD of authentic FA (100 uM) E2.

Author Contributions: A.P. designed and conducted experiments, analyzed data, and wrote a draft manuscript; N.U. designed and advised on experiments of food and natural products. C.U. designed experiments and offered comments; A.C. supplied GSO samples and information; J.B.P. supervised the study of free-radical scavenging effects of GSO in HepG2 cells and proofread the revised manuscript; S.S. conceived of and designed the study \& experiments, and contributed to the discussion and the proofreading of the manuscript. All authors have read and approved of the final draft of the manuscript.

Funding: This work was funded by the Research and Researchers for Industries (RRI) PhD. Program, Thailand Science Research and Innovation (formerly Thailand Research Fund) (PHD56I0036); British Council-Newton Fund (PhD. Placement) through Miss Adchara Prommaban; and the Faculty of Medicine Endowment Fund, Chiang Mai University through Associate Professor Somdet Srichairatanakool, PhD (015/2560).

Acknowledgments: We gratefully acknowledge the Research and Researchers for Industries (RRI) Program through Adchara Prommaban (PHD56I0036) of Thailand Science Research and Innovation (formerly Thailand Research Fund), Newton Fund (Placement of Adchara Prommaban) through Thailand British Council and Thailand Research Fund, the Faculty of Medicine Endowment Fund, Chiang Mai University through Associate Professor 
Somdet Srichairatanakool, for providing funding, as well as Tipco BioTech Company, Prachuapkhirikhan, Thailand for supplying the guava seed oil. We thank Russell K. Hollis at the Language Center, Chiang Mai University and John B. Porter for the proofreading of the manuscript.

Conflicts of Interest: The authors declare no conflict of interest.

\section{Abbreviations}

AA

ALA

$\mathrm{BF}_{3}$

Br-MMC

$\mathrm{CO}$

DCF

DCFH-DA

DI

DMEM

$\mathrm{DPPH}$

$\mathrm{EC}_{50}$

ESI

F

FBS

FI

GAE

GC/MS

GSO

HPLC-ESI/MS

HPLC-ESI-QTOF/MS

HepG2

HPLC/FLD

$\mathrm{H}_{2} \mathrm{O}_{2}$

LA

LAE

LOD

LOQ

$\mathrm{M}$

MMC-FA

MSTFA

$m / z$

ND

OA

OD

$P$.

P-12

PA

PDA

PLA

Ppm

PUFA

ROS

SA arachidonic acid

$\alpha$-linolenic acid

boron trifluoride

4-bromomethyl-7-methoxycoumarin

corn oil

dichlorofluorescein

$2^{\prime}, 7^{\prime}$-dichlorodihydrofluorescein diacetate

deionized water

Dulbecco's modified Eagle medium

1,1-diphenyl-2-picrylhydrazyl

a half effective concentration

electrospray ionization

female

fetal bovine serum

fluorescent intensity

gallic acid equivalent

gas chromatography/mass spectrometry

guava seed oil

high-performance liquid chromatography-electrospray ionization/mass spectrometry

high-performance liquid chromatography-electrospray ionization-quadrupole time of

flight/mass spectrometry

human hepatocellular carcinoma cells

high-performance liquid chromatography/fluorescence detection

hydrogen peroxide

linoleic acid

linoleic acid equivalent

limit of detection

limit of quantitation

male

methyl-7-methoxycoumarin fatty acid

$\mathrm{N}$-methyl- $\mathrm{N}$-trimethylsilyltrifluoroacetamide

mass to charge ratio

not determined

oleic acid

optical density

Psidium

nepheochromocytoma cell

palmitic acid

photodiode array

palmitoleic acid

part per million

polyunsaturated fatty acid

reactive oxygen species

stearic acid 


$\begin{array}{ll}\text { SD } & \text { standard deviation } \\ \text { SEM } & \text { standard error of mean } \\ \text { SH-SY5Y and SK-N-SH } & \text { human neuroblastoma cells } \\ \text { TC } & \text { total cholesterol } \\ \text { TE } & \text { Trolox equivalent } \\ \text { TG } & \text { triglyceride } \\ \text { TIC } & \text { total ion chromatogram } \\ \text { TMS } & \text { trimethylsilyl } \\ \text { Trolox } & \text { 6-hydroxy-2,5,7,8-tetramethylchroman-2-carboxylic acid } \\ \text { trypsin-EDTA } & \text { trypsin-ethylene diamine tetraacetic acid } \\ \mathrm{T}_{\mathrm{R}} & \text { retention time }\end{array}$

\section{References}

1. Gutierrez, R.M.; Mitchell, S.; Solis, R.V. Psidium guajava: A review of its traditional uses, phytochemistry and pharmacology. J. Ethnopharmacol. 2008, 117, 1-27. [CrossRef]

2. Morais-Braga, M.F.B.; Carneiro, J.N.P.; Machado, A.J.T.; dos Santos, A.T.L.; Sales, D.L.; Lima, L.F.; Figueredo, F.G.; Coutinho, H.D.M. Psidium guajava L., from ethnobiology to scientific evaluation: Elucidating bioactivity against pathogenic microorganisms. J. Ethnopharmacol. 2016, 194, 1140-1152. [CrossRef] [PubMed]

3. Conde Garcia, E.A.; Nascimento, V.T.; Santiago Santos, A.B. Inotropic effects of extracts of Psidium guajava L. (guava) leaves on the guinea pig atrium. Braz. J. Med. Biol. Res. 2003, 36, 661-668. [CrossRef] [PubMed]

4. Ojewole, J.A.O. Hypoglycemic and hypotensive effects of Psidium guajava Linn. (Myrtaceae) leaf aqueous extract. Methods Find. Exp. Clin. Pharm. 2006, 27, 689-695. [CrossRef] [PubMed]

5. Ojewole, J.A.O.; Awe, E.O.; Chiwororo, W.D.H. Antidiarrhoeal activity of Psidium guajava Linn. (Myrtaceae) leaf aqueous extract in rodents. J. Smooth Muscle Res. 2008, 44, 195-207. [CrossRef] [PubMed]

6. Deguchi, Y.; Miyazaki, K. Anti-hyperglycemic and anti-hyperlipidemic effects of guava leaf extract. Nutr. Metab. 2010, 7, 1-10. [CrossRef] [PubMed]

7. Adesida, A.; Farombi, E.O. Free radical scavenging activities of guava extract in vitro. Afr. J. Med. Med. Sci. 2012, 41, 81-90.

8. Sen, S.S.; Sukumaran, V.; Giri, S.S.; Park, S.C. Flavonoid fraction of guava leaf extract attenuates lipopolysaccharide-induced inflammatory response via blocking of NF-kappaB signalling pathway in Labeo rohita macrophages. Fish. Shellfish Immunol. 2015, 47, 85-92. [CrossRef]

9. Bontempo, P.; Doto, A.; Miceli, M.; Mita, L.; Benedetti, R.; Nebbioso, A.; Veglione, M.; Rigano, D.; Cioffi, M.; Sica, V.; et al. Psidium guajava L. anti-neoplastic effects: Induction of apoptosis and cell differentiation. Cell Prolif. 2012, 45, 22-31. [CrossRef]

10. Nair, S.; Nagar, R.; Gupta, R. Antioxidant phenolics and flavonoids in common Indian foods. J. Assoc. Physicians India 1998, 46, 708-710.

11. Opute, F.I. The component fatty acids of Psidium guajava seed fats. J. Sci. Food Agric. 1978, 29, 737-738. [CrossRef]

12. Bernardino-Nicanor, A.; Anon, M.C.; Scilingo, A.A.; Davila-Ortiz, G. Functional properties of guava seed glutelins. J. Agric. Food Chem. 2005, 53, 3613-3617. [CrossRef]

13. Chang, Y.P.; Tan, M.P.; Lok, W.L.; Pakianathan, S.; Supramaniam, Y. Making use of guava seed (Psidium guajava L): The effects of pre-treatments on its chemical composition. Plant. Foods Hum. Nutr. 2014, 69, 43-49. [CrossRef]

14. Michael, H.N.; Salib, J.Y.; Ishak, M.S. Acylated flavonol glycoside from Psidium gauijava L. seeds. Die. Pharm. 2002, 57, 859-860.

15. Biegelmeyer, R.; Andrade, J.M.M.; Aboy, A.L.; Apel, M.A.; Dresch, R.R.; Marin, R.; Raseira, M.d.C.B.; Henriques, A.T. Comparative analysis of the chemical composition and antioxidant activity of red (Psidium cattleianum) and yellow (Psidium cattleianum var. lucidum) strawberry guava fruit. J. Food Sci. 2011, 76, C991-C996. [CrossRef] [PubMed]

16. Salib, J.Y.; Michael, H.N. Cytotoxic phenylethanol glycosides from Psidium guaijava seeds. Phytochem 2004, 65, 2091-2093. [CrossRef] [PubMed] 
17. Malacrida, C.R.; Jorge, N. Fatty acids and some antioxidant compounds of Psidium guaijava seed oil. Acta Aliment. 2013, 42, 371-378. [CrossRef]

18. Arain, A.; Sherazi, S.T.H.; Mahesar, S.A.; Sirajuddin. Spectroscopic and chromatographic evaluation of solvent extracted guava seed oil. Int. J. Food Prop. 2017, 20, S556-S563. [CrossRef]

19. Garg, S.; Talwar, G.P.; Upadhyay, S.N. Comparison of extraction procedures on the immunocontraceptive activity of neem seed extracts. J. Ethnopharmacol. 1994, 44, 87-92. [CrossRef]

20. Adeleke, M.A.; Popoola, S.A.; Agbaje, W.B.; Adewale, B.; Adeoye, M.D.; Jimoh, W.A. Larvicidal efficacy of seed oils of Pterocarpus santalinoides and tropical Manihot species against Aedes aegypti and effects on aquatic fauna. Tanzan J. Health Res. 2009, 11, 250-252. [CrossRef]

21. Hossain, S.J.; Islam, M.R.; Pervin, T.; Iftekharuzzaman, M.; Hamdi, O.A.A.; Mubassara, S.; Saifuzzaman, M.; Shilpi, J.A. Antibacterial, anti-diarrhoeal, analgesic, cytotoxic activities, and GC-MS profiling of Sonneratia apetala (Buch.-Ham.) Seed. Prev. Nutr. Food Sci. 2017, 22, 157-165.

22. Huang, H.Y.; Chang, C.K.; Tso, T.K.; Huang, J.J.; Chang, W.W.; Tsai, Y.C. Antioxidant activities of various fruits and vegetables produced in Taiwan. Int. J. Food Sci. Nutr. 2004, 55, 423-429. [CrossRef]

23. Pelegrini, P.B.; Murad, A.M.; Silva, L.P.; dos Santos, R.C.P.; Costa, F.T.; Tagliari, P.D.; Bloch Jr, C.; Noronha, E.F.; Miller, R.N.G.; Franco, O.L. Identification of a novel storage glycine-rich peptide from guava (Psidium guajava) seeds with activity against Gram-negative bacteria. Peptides 2008, 29, 1271-1279. [CrossRef]

24. Prommaban, A.; Utama-Ang, N.; Chaikitwattana, A.; Uthaipibull, C.; Srichairatanakool, S. Linoleic acid-rich guava seed oil: Safety and bioactivity. Phytother. Res. 2019, 33, 2749-2764. [CrossRef]

25. Chen, H.J.; Inbaraj, B.S.; Chen, B.H. Determination of phenolic acids and flavonoids in Taraxacum formosanum Kitam by liquid chromatography-tandem mass spectrometry coupled with a post-column derivatization technique. Int. J. Mol. Sci. 2012, 13, 260-285. [CrossRef]

26. Yu, F.; Qian, H.; Zhang, J.; Sun, J.; Ma, Z. Simultaneous quantification of eight organic acid components in Artemisia capillaris Thunb (Yinchen) extract using high-performance liquid chromatography coupled with diode array detection and high-resolution mass spectrometry. J. Food Drug Anal. 2018, 26, 788-795. [CrossRef]

27. Baeza, G.; Sarria, B.; Bravo, L.; Mateos, R. Exhaustive qualitative LC-DAD-MSn analysis of arabica green coffee beans: Cinnamoyl-glycosides and cinnamoylshikimic acids as new polyphenols in green coffee. J. Agric. Food Chem. 2016, 64, 9663-9674. [CrossRef] [PubMed]

28. Plazonic, A.; Bucar, F.; Males, Z.; Mornar, A.; Nigovic, B.; Kujundzic, N. Identification and quantification of flavonoids and phenolic acids in burr parsley (Caucalis platycarpos L.), using high-performance liquid chromatography with diode array detection and electrospray ionization mass spectrometry. Molecules 2009, 14, 2466-2490. [CrossRef] [PubMed]

29. Ma, J.Y.; Zhou, X.; Fu, J.; Hu, T.; Or, P.M.; Feng, R.; He, C.Y.; Chen, W.J.; Zhang, X.; Chen, Y.; et al. Metabolite profiling analysis of FR429, an ellagitannin purified from Polygonum capitatum, in rat and human liver microsomes, cytosol and rat primary hepatocytes in vitro. Chem. Biol. Interact. 2014, 220, 33-40. [CrossRef] [PubMed]

30. Ma, J.Y.; Zhou, X.; Fu, J.; He, C.Y.; Feng, R.; Huang, M.; Shou, J.W.; Zhao, Z.X.; Li, X.Y.; Zhang, L.; et al. In vivo metabolite profiling of a purified ellagitannin isolated from polygonum capitatum in rats. Molecules 2016, 21, 1110. [CrossRef] [PubMed]

31. Simirgiotis, M.J.; Benites, J.; Areche, C.; Sepulveda, B. Antioxidant capacities and analysis of phenolic compounds in three endemic Nolana species by HPLC-PDA-ESI-MS. Molecules 2015, 20, 11490-11507. [CrossRef] [PubMed]

32. Xia, J.X.; Zhao, B.B.; Zan, J.F.; Wang, P.; Chen, L.L. Simultaneous determination of phenolic acids and flavonoids in Artemisiae Argyi Folium by HPLC-MS/MS and discovery of antioxidant ingredients based on relevance analysis. J. Pharm. Biomed. Anal. 2019, 175, 112734. [CrossRef]

33. Hossain, M.B.; Rai, D.K.; Brunton, N.P.; Martin-Diana, A.B.; Barry-Ryan, C. Characterization of phenolic composition in Lamiaceae spices by LC-ESI-MS/MS. J. Agric. Food Chem. 2010, 58, 10576-10581. [CrossRef] [PubMed]

34. Tang, J.; Dunshea, F.R.; Suleria, H.A.R. LC-ESI-QTOF/MS characterization of phenolic compounds from medicinal plants (hops and juniper berries) and their antioxidant activity. Foods 2020, 9, 7. [CrossRef] [PubMed] 
35. Gu, C.; Howell, K.; Dunshea, F.R.; Suleria, H.A.R. LC-ESI-QTOF/MS characterisation of phenolic acids and flavonoids in polyphenol-rich fruits and vegetables and their potential antioxidant activities. Antioxidants 2019, 8, 405. [CrossRef] [PubMed]

36. Jimenez, C.; Crews, P. Novel marine sponge amino acids, 10. Xestoaminols from Xestospongia sp. J. Nat. Prod. 1990, 53, 978-982. [CrossRef] [PubMed]

37. Phillip, D.; Hobe, S.; Paulsen, H.; Molnar, P.; Hashimoto, H.; Young, A.J. The binding of Xanthophylls to the bulk light-harvesting complex of photosystem II of higher plants. A specific requirement for carotenoids with a 3-hydroxy-beta-end group. J. Biol. Chem. 2002, 277, 25160-25169. [CrossRef]

38. Burdi, D.K.; Samejo, M.Q.; Bhanger, M.I.; Khan, K.M. Fatty acid composition of Abies pindrow (west himalayan fir). Pak. J. Pharm. Sci. 2007, 20, 15-19.

39. Mohamed, M.H.; Wilson, L.D.; Headley, J.V. Tunable polymeric sorbent materials for fractionation of model naphthenates. J. Phys. Chem. B 2013, 117, 3659-3666. [CrossRef]

40. Nenoff, P.; Haustein, U.F. In vitro activity of phytosphingosines against Malassezia furfur and Candida albicans. Acta Derm. Venereol. 2002, 82, 170-173. [CrossRef]

41. Oh, M.J.; Cho, Y.H.; Cha, S.Y.; Lee, E.O.; Kim, J.W.; Kim, S.K.; Park, C.S. Novel phytoceramides containing fatty acids of diverse chain lengths are better than a single C18-ceramide N-stearoyl phytosphingosine to improve the physiological properties of human stratum corneum. Clin. Cosmet. Investig. Derm. 2017, 10, 363-371. [CrossRef] [PubMed]

42. Dasyam, N.; Munkacsi, A.B.; Fadzilah, N.H.; Senanayake, D.S.; O'Toole, R.F.; Keyzers, R.A. Identification and bioactivity of 3-epi-xestoaminol C isolated from the New Zealand brown alga Xiphophora chondrophylla. J. Nat. Prod. 2014, 77, 1519-1523. [CrossRef]

43. Hormaetxe, K.; Hernandez, A.; Becerril, J.M.; Garcia-Plazaola, J.I. Role of red carotenoids in photoprotection during winter acclimation in Buxus sempervirens leaves. Plant. Biol. 2004, 6, 325-332. [CrossRef] [PubMed]

44. Da Silva, A.C.; Jorge, N. Bioactive compounds of oils extracted from fruits seeds obtained from agroindustrial waste. Eur. J. Lipid Sci. Tech. 2016, 118, 1600024. [CrossRef]

45. Beveridge, T.H.; Li, T.S.; Drover, J.C. Phytosterol content in American ginseng seed oil. J. Agric. Food Chem. 2002, 50, 744-750. [CrossRef] [PubMed]

46. Hassan, E.M.; Matloub, A.A.; Aboutabl, M.E.; Ibrahim, N.A.; Mohamed, S.M. Assessment of anti-inflammatory, antinociceptive, immunomodulatory, and antioxidant activities of Cajanus cajan $\mathrm{L}$. seeds cultivated in Egypt and its phytochemical composition. Pharm. Biol. 2015, 54, 1380-1391. [CrossRef]

47. Hamedi, A.; Ghanbari, A.; Razavipour, R.; Saeidi, V.; Zarshenas, M.M.; Sohrabpour, M.; Azari, H. Alyssum homolocarpum seeds: Phytochemical analysis and effects of the seed oil on neural stem cell proliferation and differentiation. J. Nat. Med. 2015, 69, 387-396. [CrossRef]

48. Kozlowska, M.; Gruczynska, E.; Scibisz, I.; Rudzinska, M. Fatty acids and sterols composition, and antioxidant activity of oils extracted from plant seeds. Food Chem. 2016, 213, 450-456. [CrossRef]

49. Kalleli, F.; Bettaieb Rebey, I.; Wannes, W.A.; Boughalleb, F.; Hammami, M.; Saidani Tounsi, M.; M’Hamdi, M. Chemical composition and antioxidant potential of essential oil and methanol extract from Tunisian and French fennel (Foeniculum vulgare Mill.) seeds. J. Food Biochem. 2019, 43, e12935. [CrossRef]

50. Kayano, S.; Yamada, N.F.; Suzuki, T.; Ikami, T.; Shioaki, K.; Kikuzaki, H.; Mitani, T.; Nakatani, N. Quantitative evaluation of antioxidant components in prunes (Prunus domestica L.). J. Agric. Food Chem. 2003, 51, 1480-1485. [CrossRef]

51. Costa, F.; Jerz, G.; Figueiredo Fde, S.; Winterhalter, P.; Leitao, G.G. Solvent system selectivities in countercurrent chromatography using Salicornia gaudichaudiana metabolites as practical example with off-line electrospray mass-spectrometry injection profiling. J. Chromatogr. A 2015, 1385, 20-27. [CrossRef] [PubMed]

52. Gonzalez-Cortazar, M.; Herrera-Ruiz, M.; Zamilpa, A.; Jimenez-Ferrer, E.; Marquina, S.; Alvarez, L.; Tortoriello, J. Anti-inflammatory activity and chemical profile of Galphimia glauca. Planta Med. 2013, 80, 90-96. [CrossRef] [PubMed]

53. Jho, E.H.; Kang, K.; Oidovsambuu, S.; Lee, E.H.; Jung, S.H.; Shin, I.S.; Nho, C.W. Gymnaster koraiensis and its major components, 3,5-di-O-caffeoylquinic acid and gymnasterkoreayne B, reduce oxidative damage induced by tert-butyl hydroperoxide or acetaminophen in HepG2 cells. BMB Rep. 2013, 46, 513-518. [CrossRef] [PubMed] 
54. Lee, S.G.; Lee, H.; Nam, T.G.; Eom, S.H.; Heo, H.J.; Lee, C.Y.; Kim, D.O. Neuroprotective effect of caffeoylquinic acids from Artemisia princeps Pampanini against oxidative stress-induced toxicity in PC-12 cells. J. Food Sci. 2011, 76, C250-C256. [CrossRef] [PubMed]

55. Kayano, S.; Kikuzaki, H.; Fukutsuka, N.; Mitani, T.; Nakatani, N. Antioxidant activity of prune (Prunus domestica L.) constituents and a new synergist. J. Agric. Food Chem. 2002, 50, 3708-3712. [CrossRef]

56. Menichini, F.; Losi, L.; Bonesi, M.; Pugliese, A.; Loizzo, M.R.; Tundis, R. Chemical profiling and in vitro biological effects of Cardiospermum halicacabum L. (Sapindaceae) aerial parts and seeds for applications in neurodegenerative disorders. J. Enzym. Inhib. Med. Chem. 2013, 29, 677-685. [CrossRef]

57. Kenny, O.; Smyth, T.J.; Hewage, C.M.; Brunton, N.P. Antioxidant properties and quantitative UPLC-MS analysis of phenolic compounds from extracts of fenugreek (Trigonella foenum-graecum) seeds and bitter melon (Momordica charantia) fruit. Food Chem. 2013, 141, 4295-4302. [CrossRef]

58. Ablat, A.; Halabi, M.F.; Mohamad, J.; Hasnan, M.H.; Hazni, H.; Teh, S.H.; Shilpi, J.A.; Mohamed, Z.; Awang, K. Antidiabetic effects of Brucea javanica seeds in type 2 diabetic rats. BMC Complement. Altern. Med. 2017, 17, 94-107. [CrossRef]

59. Arranz, S.; Cert, R.; Pérez-Jiménez, J.; Cert, A.; Saura-Calixto, F. Comparison between free radical scavenging capacity and oxidative stability of nut oils. Food Chem. 2008, 110, 985-990. [CrossRef]

60. Gorinstein, S.; Martin-Belloso, O.; Katrich, E.; Lojek, A.; Ciz, M.; Gligelmo-Miguel, N.; Haruenkit, R.; Park, Y.S.; Jung, S.T.; Trakhtenberg, S. Comparison of the contents of the main biochemical compounds and the antioxidant activity of some Spanish olive oils as determined by four different radical scavenging tests. J. Nutr. Biochem. 2003, 14, 154-159. [CrossRef]

61. Assiri, A.M.; Hassanien, M.F. Bioactive lipids, radical scavenging potential, and antimicrobial properties of cold pressed clove (Syzygium aromaticum) oil. J. Med. Food 2013, 16, 1046-1056. [CrossRef] [PubMed]

62. Ali, Q.; Anwar, F.; Ashraf, M.; Saari, N.; Perveen, R. Ameliorating effects of exogenously applied proline on seed composition, seed oil quality and oil antioxidant activity of maize (Zea mays L.) under drought stress. Int. J. Mol. Sci. 2013, 14, 818-835. [CrossRef]

63. Alu'datt, M.H.; Rababah, T.; Alhamad, M.N.; Al-Mahasneh, M.A.; Almajwal, A.; Gammoh, S.; Ereifej, K.; Johargy, A.; Alli, I. A review of phenolic compounds in oil-bearing plants: Distribution, identification and occurrence of phenolic compounds. Food Chem. 2017, 218, 99-106. [CrossRef] [PubMed]

64. Zhang, L.Z.; Liu, R.H. Phenolic and carotenoid profiles and antiproliferative activity of foxtail millet. Food Chem. 2014, 174, 495-501. [CrossRef]

65. Zhang, L.; Liu, R.; Niu, W. Phytochemical and antiproliferative activity of proso millet. PLoS ONE 2014, 9, e104058. [CrossRef] [PubMed]

66. Kim, S.S.; Park, R.Y.; Jeon, H.J.; Kwon, Y.S.; Chun, W. Neuroprotective effects of 3,5-dicaffeoylquinic acid on hydrogen peroxide-induced cell death in SH-SY5Y cells. Phytother. Res. 2005, 19, 243-245. [CrossRef] [PubMed]

67. Gonzalez-Burgos, E.; Liaudanskas, M.; Viskelis, J.; Zvikas, V.; Janulis, V.; Gomez-Serranillos, M.P. Antioxidant activity, neuroprotective properties and bioactive constituents analysis of varying polarity extracts from Eucalyptus globulus leaves. J. Food Drug Anal. 2018, 26, 1293-1302. [CrossRef] [PubMed]

68. Shahat, A.A.; Hidayathulla, S.; Khan, A.A.; Alanazi, A.M.; Al Meanazel, O.T.; Alqahtani, A.S.; Alsaid, M.S.; Hussein, A.A. Phytochemical profiling, antioxidant and anticancer activities of Gastrocotyle hispida growing in Saudi Arabia. Acta Trop. 2019, 191, 243-247. [CrossRef]

69. Chung, M.J.; Lee, S.; Park, Y.I.; Lee, J.; Kwon, K.H. Neuroprotective effects of phytosterols and flavonoids from Cirsium setidens and Aster scaber in human brain neuroblastoma SK-N-SH cells. Life Sci. 2016, 148, 173-182. [CrossRef]

70. Asadi, F.; Shahriari, A.; Chahardah-Cheric, M. Effect of long-term optional ingestion of canola oil, grape seed oil, corn oil and yogurt butter on serum, muscle and liver cholesterol status in rats. Food Chem. Toxicol. 2010, 48, 2454-2457. [CrossRef]

71. Mekonnen, Z.; Gebreselema, A.; Abere, Y. Effect of locally manufactured niger seed oil on lipid profile compared to imported palm and sunflower oils on rat models. J. Lipids 2018, 2018, 8. [CrossRef] [PubMed]

72. Sakono, M.; Yoshida, K.; Yahiro, M. Combined effects of dietary protein and fat on lipid metabolism in rats. J. Nutr. Sci. Vitam. 1993, 39, 335-343. [CrossRef] 
73. Jurgonski, A.; Juskiewicz, J.; Zdunczyk, Z.; Krol, B. Caffeoylquinic acid-rich extract from chicory seeds improves glycemia, atherogenic index, and antioxidant status in rats. Nutrition 2011, 28, 300-306. [CrossRef] [PubMed]

74. Pieszka, M.; Tombarkiewicz, B.; Roman, A.; Migdal, W.; Niedziolka, J. Effect of bioactive substances found in rapeseed, raspberry and strawberry seed oils on blood lipid profile and selected parameters of oxidative status in rats. Environ. Toxicol. Pharm. 2013, 36, 1055-1062. [CrossRef] [PubMed]

75. Zahir, A.A.; Rahuman, A.A.; Kamaraj, C.; Bagavan, A.; Elango, G.; Sangaran, A.; Kumar, B.S. Laboratory determination of efficacy of indigenous plant extracts for parasites control. Parasitol. Res. 2009, 105, 453-461. [CrossRef] [PubMed]

76. Lee, J.Y.; Park, N.H.; Lee, W.; Kim, E.H.; Jin, Y.H.; Seo, E.K.; Hong, J. Comprehensive chemical profiling of Pinellia species tuber and processed Pinellia tuber by gas chromatography-mass spectrometry and liquid chromatography-atmospheric pressure chemical ionization-tandem mass spectrometry. J. Chromatogr. A 2016, 1471, 164-177. [CrossRef]

77. Cuyckens, F.; Claeys, M. Optimization of a liquid chromatography method based on simultaneous electrospray ionization mass spectrometric and ultraviolet photodiode array detection for analysis of flavonoid glycosides. Rapid Commun. Mass Spectrom. 2002, 16, 2341-2348. [CrossRef]

78. Kano, M.; Takayanagi, T.; Harada, K.; Makino, K.; Ishikawa, F. Antioxidative activity of anthocyanins from purple sweet potato, Ipomoera batatas cultivar Ayamurasaki. Biosci. Biotechnol. Biochem. 2005, 69, 979-988. [CrossRef]

79. Pangjit, K.; Udomsuk, L.; Upanan, S.; Pongjanta, A.; Chansiw, N.; Srichairatanakool, S. Iron-chelating and anti-hemolytic properties of ethanolic extract of lotus (Nelumbonucifera gaertn) leaves. J. Med. Assoc. Thai. 2016, 99, S58-S66.

80. Agarwala, S.; Rao B., N.; Mudholkar, K.; Bhuwania, R.; Satish Rao, B.S. Mangiferin, a dietary xanthone protects against mercury-induced toxicity in HepG2 cells. Env. Toxicol. 2012, 27, 117-127. [CrossRef]

81. Shen, L.; Zhao, H.Y.; Du, J.; Wang, F. Anti-tumor activities of four chelating agents against human neuroblastoma cells. In Vivo 2005, 19, 233-236. [PubMed]

82. Puttmann, M.; Krug, H.; von Ochsenstein, E.; Kattermann, R. Fast HPLC determination of serum free fatty acids in the picomole range. Clin. Chem. 1993, 39, 825-832. [CrossRef] [PubMed]

Sample Availability: Samples are available from the authors.

(C) 2020 by the authors. Licensee MDPI, Basel, Switzerland. This article is an open access article distributed under the terms and conditions of the Creative Commons Attribution (CC BY) license (http://creativecommons.org/licenses/by/4.0/). 